Şırnak Üniversitesi

Ilahiyat Fakültesi Dergisi

Sayı 26 Haziran 2021

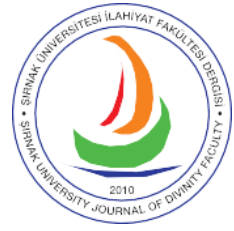

e-ISSN 2667-6575
Şırnak University

Journal of Divinity Faculty

Issue 26 June 2021

\title{
Arap Dil Bilginlerinin Zarûret Olgusu Hakkındaki Yaklaşımları
}

The Approaches of Arabic Linguists on the Phenomenon of Necessity

\section{Muhammed Meşhud HAKÇIOĞLU}

Öğr. Gör., Van Yüzüncü Yıl Üniversitesi, İlahiyat Fakültesi, Arap Dili ve Belagati Ana Bilim Dalı Lecturer, Van Yüzüncü Yal University, Faculty of Theology, Department of Arabic Langauge and Rhetoric

Van, Turkey muhammed yyu@hotmail.com https://orcid.org/0000-0003-3894-2231

\section{Makale Bilgisi / Article Information}

Makale Türü / Article Types: Araştırma Makalesi / Research Article

Geliş Tarihi / Received: 11 Şubat / February 2021

Kabul Tarihi / Accepted: 15 Mart / March 2021

Yayın Tarihi / Published: 15 Haziran / June 2021

Sayı / Issue: 26 Sayfa / Pages: 206-232

Atıf / Cite as: Hakçığlu, Muhammed Meşhud. "Arap Dil Bilginlerinin Zarûret Olgusu Hakkındaki Yaklaşımları [The Approaches of Arabic Linguists on the Phenomenon of Necessity]". Şırnak Üniversitesi İlahiyat Fakültesi Dergisi - Şırnak University Journal of Divinity Faculty 26 (June 2021), 206232. https://doi.org/10.35415/sirnakifd.878887

Etik Beyanı / Ethics Declaration: Bu makalede bilimsel araştırma ve yayın etiği ilkelerine riayet edilmiştir. Makale etik izin gerektirmeyen bir çalışma olup en az iki hakem tarafından incelenmiş ve intihal içermediği teyit edilmiştir. / In this article, the principles of scientific research and publication ethics are respected. The article is a study that does not require ethical permission. It has been reviewed by at least two referees and was confirmed that it did not contain plagiarism. 


\section{Özet}

Zarûret; Arap dil bilginleri ve eleştirmenlerin eserlerinde dağınık bir şekilde ortaya konulan morfolojik ve gramatik birçok dilsel olgu için kullanılan bir kavramdır. Eski Arap şiirlerinde, Arap dilinin alışılagelmiş kurallarının dışına çıkılmış olup "şiir zarûreti" terimiyle ifade edilen çeşitli kural dışı kullanımlara karşı, eleştirmenlerin ve dilcilerin görüş, tavır ve yaklaşımları çeşitlilik göstermiştir. Dil bilginleri, nahiv alanındaki eserlerini oluştururken zarûret konusuna da değinmişlerdir. Bu, zarûretin nahiv konuları içerisinde olması itibariyle değil de kendileri için kolay bir çıkış yolu olma hasebiyledir. Zarûret olgusu hakkında temelde birbirine zıt iki görüşün olduğu görülmektedir. Şairin mecbur kalıp kalmamasına bakılmaksızın şiirde vukû bulan kuraldışı her kullanımı kabul edip zarûretin alanını genişleten görüş ile zarûreti, sadece şairin mecbûr kalmasıyla kayıtlayan yani şairin o kullanımın yerine başka bir kullanım bulamamasından ötürü olması şeklinde iki görüşün olduğu görülmektedir. Birinci görüşün temsilcileri kendisine nisbet edilen farklı iki görüşten birinin sahibi olan Sîbeveyhi ve İbn Cinnî̀nin başını çektiği dil bilginlerin çoğunluğu iken ikinci görüşün temsilcisi ise Sîbeveyhi'ye nisbet edilen diğer ikinci görüşe göre Sîbeveyhi ve İbn Mâlik'tir. Bunun yanında Ahfeş, şairlere has bir durum olarak zarûretin şairlerin dil alışkanlıkların ötürü normal kelamlarında da câiz olduğu görüşünde iken İbn Fâris ise şiirde dil kurallarına aykırı olarak görülen bu kullanımların hatadan başka bir şey olmadığını söyleyerek zarûret olgusunun olmadığını savunmuştur. Bu yönden bakıldığında zarûret hakkında dört farklı görüşün olduğu görülmektedir. Zarûret olgusu hakkında bu ihtilâfların olmasının sebebi dil bilginlerin şiir dili ile nesir dilini birbirinden ayırt etmemeleridir. Dil bilginleri normal kelamda ortaya koydukları dil kaidelerini şiire de uygulamak istediklerinden şiirdeki vezin ve kâfiye zorunluluğundan ötürü normal kelamdaki dil kaidelerine aykırı gelen kullanımları, zarûret olgusu olarak değerlendirmişlerdir. Dil bilginleri dil kaidelerini ortaya koyarken şiirden istişhâd getirmişlerdir. Bazen de şiirdeki kullanımların bu dil kaidelerine aykırı olarak cereyan ettiği görülmüştür. Bu itibar ile zarûret olgusu hakkında birçok yönden görüş farklılığının ortaya çıktığı görülmektedir. Bazıları kuraldışı bu kullanımları şiir dilinden kaynaklı şairin bir zorunluluktan ötürü başvurduğu zarûret olgusu altına koyarken, diğer bazıları da bu kullanımların Arap kelamına has kullanım olduğunu öne sürerek bunu zarûret konusu altına koymanın câiz olamayacağını ifade etmiş, diğer bazıları da bunun şaz kullanım olduğunu öne sürmüştür. Dil bilginleri arasında zarûret olgusunun şaire verilen bir ruhsat $\mathrm{m} 1$ yoksa şâz kullanım mı olduğu hususunda da ihtilâf mevcuttur. Dil bilginleri diğer dil kurallarını ortaya koydukları gibi dilsel bir olgu olarak zarûret olgusuna bakmadıklarından bu konuda görüş birliği oluşmamış ve nahiv kitaplarında bu olgunun genel bir çerçevesi çizilmeden ortaya konulmuştur. Dil bilginleri, zarûret olarak kabul edilen kullanımları, iki illetten birine döndürmüşlerdir. Bu iki illetin birincisi câiz olmayan bir şeyi câiz olana teşbih etmek şeklinde iken ikinci illet ise bir kelimeyi aslına döndürmektir. Dil bilginlerinin bu iki illete başvurmalarının sebebi zarûret olgusunu dil kaideleri ölçüsü çerçevesine koymaktır. Genel itibariyle Eski Arap şiir dilinin bir tezahürü olarak ortaya çıkan zaruret olgusuna dair nitelikli kullanımlar ve yapılar gerek müstakil eserlerde gerekse dil ve edebiyat kaynaklarında genellikle konu tasnif yöntemi ile bazen de nitel bir yaklaşımla güzel ve çirkin oluşuna göre ele alınmıştır. Bu kaynaklarda zarûret olgusu; şiir, ayet, hadis, atasözü gibi edebî, tarihî ve dini metinler üzerinden işlenmiştir. Bu çalışmada da dil bilginlerinin zarûret olgusuna dair yaklaşımları eleştirel bir bakış açısıyla irdelenmeye çalışılacaktır.

Anahtar Kelimeler: Arap Dili ve Belagati, Nahiv, Şiir, Zarûret, Olgu, Dil Bilginleri. 


\section{Summary}

Necessity is a concept used for many morphological and grammatical linguistic phenomena that are scattered in the works of Arabic linguists and critics. In ancient Arabic poems, the usual rules of the Arabic language were broken and the views, attitudes and approaches of critics and linguists varied on the various irregular uses expressed by the term "poetry necessity". Linguists also touched upon the subject of necessity while creating their works in the field of syntax. This is not because the necessity is among the syntax issues, but because it is an easy way out for them. It seems that there are two fundamentally opposite views about the phenomenon of necessity: The view that accepts every ungrammatical use that occurs in poetry and expands the scope of necessity, regardless of whether the poet is compelled or not, and the view that accepts the necessity only because the poet had to, that is, because the poet could not find another use instead of that usage. While the representatives of the first view are the majority of the linguists led by Sîbeveyhi and Ibn Jinni, the second view is represented by of Ibn Malik. In addition, Ahfesh believes that necessity, which is a special case for poets, is also appropriate in the normal words of poets due to their language habits, while Ibn Faris argued that there is no phenomenon of necessity, saying that these uses, which are considered contrary to the rules of language in poetry, are nothing but mistakes. From this point of view, it seems that there are four different views about necessity. The reason for these differences about the phenomenon of necessity is that language scholars do not distinguish between the language of poetry and the language of prose. Since linguists want to apply the language rules they use in normal speech to poetry, they considered the usage that contradicts the language rules in normal speech as a phenomenon of necessity due to the necessity of meter and rhyme in poetry. Linguists brought evidence from poetry while putting forward the rules of language. Sometimes it has been observed that the usages against these language rules occur in poetry. In this respect, there are many differences of opinion about the necessity phenomenon. Some put these ungrammatical uses under the phenomenon of necessity, which the poet resorted to because of an obligation caused by the language of poetry, while others suggested that it would not be appropriate to put it under the title of necessity as these uses were special to the Arabic language and others suggested that they were exceptional uses. Among linguistic scholars, there is also a dispute as to whether the phenomenon of necessity is a license granted to the poet or an exceptional use. Since the linguists do not see the necessity as a linguistic phenomenon, there was no consensus on this issue and this phenomenon was put forward in the syntax books without drawing a general framework. Linguists have dealt with such usages, which are considered to be necessities, through one of the two resolutions. While the first of these two resolutions is to simulate something that is not permissible to something permissible, the second is to return a word to its original. The reason why linguists resort to these two resolutions is to put the necessity phenomenon within the framework of language rules. In general, quality uses and structures of the phenomenon of necessity emerging as a manifestation of the Old Arabic poetic language, both in individual works and in language and literature sources have been handled according to their pleasant or unpleasant nature, usually with a subject classification method and sometimes with a qualitative approach. In these sources, the phenomenon of necessity has been studied through literary, historical and religious texts such as poems, verses, hadiths and proverbs. In this study, the approaches of linguists to the necessity phenomenon will be examined with a critical point of view.

Keywords: Arabic Language and Rhetoric, Syntax, Poetry, Necessity, Phenomenon, Linguists. 


\section{Giriş̧ ${ }^{1}$}

Arapça dil gramerinde dil bilginleri arasındaki ihtilâf, dil alanındaki araştırmaların başlamasından beri dilsel incelemenin en önemli konularından biridir. Bu ihtilâfın birçok sebebi bulunmaktadır. En önemli sebeplerinden biri dil bilginlerin üzerinde durup takip ettiği metodun farklılığından kaynaklanmaktadır. Bu konuyu araştıran birçok eser de te'lîf edilmiştir. Başka bir sebep de dil kaidelerini ortaya koymak için delil olarak şiirden istişhâd getirmeleridir. Bazen de şiirdeki kullanımların bu dil kaidelerine aykırı olarak cereyan ettiği görülmektedir. Dil kurallarına aykırı olarak şiirde oluşan zarûret olgusu da bunun en büyük tezahürüdür. Zarûret olgusu için belli bir tanım üzerinde dil bilginlerin ittifak etmemeleri, zarûretin istişhâd konusu olup veya olmama bağlamında ihtilâf etmelerine yol açmıştır. Bu itibar ile zarûret olgusu hakkında birçok yönden görüş farklılı̆̆ı ortaya çıkmıştır.

Ebû Bişr Sîbeveyhi'den (öl. 180/796) itibaren dil bilginleri kitaplarını te'lîf ederken dil kaideleri konuları içinde zarûret olgusuna değinmişlerdir. Sîbeveyhi'den sonraki dil bilginleri bununla yetinmeyip bizzat zarûret konusunu ele alan eserler te'lîf etmişlerdir. Bu konuda bizzat eserler te'lif eden dil bilginlerine baktığımızda; Ebu'l-Abbâs Müberred (öl. 286/900) Ḍarûretu'ş-şi'r isimli bir eser, Ebu'l-Hüseyn İbn Fâris (öl. 395/1004) Żemmu'l-hața' fi'şşi'r isimli küçük bir risale, el-Kazzâz el-Kayravânî (öl. 412/1021) Mâ yecĥzu li'ş-şấir fi'ḍ-ḍarûra, İbn 'Usfûr el-İşbîlî (öl. 669/1270) Darâiru'ş-şi'r, Muhammed Selîm Efendi (öl. 1138/1726) Mevâridu'l-beșâir li-ferâidi'ḍ-darâir, Şehâbeddin Mahmûd Âlûsî (öl. 1342/ 1924) eḍ-Darâir ve mâ yeŝ่̀gu li'ş-şấir dûne'n-nâs_ir, Muhammed Hammâse Abdullatîf (öl. 2015) Lug்atu'ş-şi'r:dirâse fi'ḍ-ḍarûreti'ş-şi'riyye, Seyyid İbrâhîm Muhammed, eḍ-Darûretu'ş-şi'riyye: dirâse uslûbiyye ve İbrâhîm Hasan İbrâhîm de Sîbeveyhi ve'ḍ-ḍarûretu'ş-şi'riyye isminde eserler ortaya koymuşlardır.

Bununla beraber zarûret olgusu konusuna kitaplarının bir bölümünde değinen dil bilginlerine baktığımızda Ebû Bekr İbnu's-Serrâc (öl. 316/929) "el-Uș̂ul fi'n-naḥv" kitabında, Ebû Saîd es-Sîrâfî (ö. 368/979), el-Kitâb'1 şerhederken باب ما يحتمل الشعر konusu altında², Ebu'1-

1 Bu çalışma “Arap Gramerinde Zarûret Olgusu” başlıklı doktora tezi esas alınarak hazırlanmıştır./ This article is extracted from doctorate dissertation entitled "The Case of Necessity in Arabic Grammar" (PhD Dissertation, Van Yüzüncü Yıl University, Van/Turkey).

2 Sîrâfî, Sîbeveyhi'nin burada zarûretlere yeteri derecede değinmediğini görüp bunun bir eksiklik olduğunu düşününce bu konuyu geniş bir şekilde ortaya koyarak eserinde bir bölüm oluşturmuştur. Burada farklı şiir zarûretlerine değinmiş, bu zarûretleri açıklamış ve hükümlerini ortaya koymuştur. Bu bölüm, müstakil bir eser olmaya layık olması hasebiyle üzerinde iki ayrı tahkik çalışması yapılmıştır. Birincisi Ramazân Abduttevvâb tarafından Darûretu'ş-şi'r isminde müstakil bir eser olarak ortaya konulmuş, ikincisi de 'İved b. 
Hasen er-Rummânî (öl. 384/994) "Şerḥu Kitâbi Sîbeveyhi" kitabının الترخيم في ضرورة الثعر bâbında, İbn Reşîk el-Kayravânî (öl. 456/1064) "el-'Umde fî Meḥ̂asini'ş-şi' r" eserinde, Saffâr elBatalyevsî (öl. 630/1232) "Şerḥu Kitâbi Sîbeveyhi" kitabında, İbn “Usfûr "Şerḥu'l-Cumel" ve "elel-Mukarrib fi'n-naḥv" kitaplarında, Hâzim el-Kartâcennî (öl. 684/1285) "Minhâcu'l-buleg̀âa" eserinde, İ̉n Mâlik et-Tâî (öl. 672/1274) "Şerḥu't-Teshîl", Ebû Hayyân el-Endelüsî (öl. 745/1344) "İrtişâfu'ḍ-ḍarab" isimli eserinde, Bahâeddîn es-Subkî (öl. 773/1372) "'Arûsu'l-efrâh" kitabında, İbrâhim b. Mûsâ eş-Şâtıbî (öl. 790/1388) “el-Mekâșidu'ş-şâfiye-Şerhu Elfiyyeti İbn Mâlik" isimli eserinde bu konuyu ele almıştır.

Ayrıca Arap dilinde zarûret olgusunu Arapça olarak kitap bölümü, doktora, yüksek lisans çalışması, makale, bildiri şeklinde araştırma konusu yapan birçok araştırmacı ve dilbilimci de bulunmaktadır. ${ }^{3}$

Türkiye' de ise bu konu detaylı bir şekilde araştırılmamıştır. İsmail Hakkı SEZER Arap Şiirinde Zarûret ve الضرورة ذروةٌ مرموقة مطموعة لا رخصةٌ مشروعة بَلْهَ أن تكون غلطة ممنوعة "Zarûret umulan güzide bir zirvedir. Memnu bir hata olmasını bırak meşru bir ruhsat dahi değildir" isminde iki küçük eser ortaya koymuş, M. Faruk TOPRAK, Klasik Arap Şiir ve Nesrinde Kuraldışı Kullanımlar isminde seri halinde üç makale kaleme almış, Eyyüp TANRIVERDİ'nin Eski Arap Şiirinde Kuraldı̧̧ Kullanımlar Literatürü isminde bir makalesi, Aladdin GÜLTEKİN'in Arap Şiirinde Zorunluluktan Kaynaklanan Hazif Olgusu adında bir makalesi, Amer al-JARAH'ın da - SSiir Zarûreti' Kavrammmn Anlamı ve Fuhûle Kavramıyla Bağlantısı:-Ferezdak'da İkvâ Örneği- isminde bir makalesi bulunmaktadır. Biz de inşaallah bu çalışmamızda dil bilginleri arasında zarûret olgusunun hakikatini irdelemeye çalışacağız.

\section{Zarûret Kavramı}

Zarûret kelimesinin sözlükte ne anlama geldiğine bakıldığında Halîl b. Ahmed elFerâhîdî (öl. 175/791) zarûretin, iztirâr/ الاضطر kelimesinin ism-i mastarı olduğunu söylemiş olup sözlük kitaplarında bu kelime genel itibariyle ihtiyaç, mecburiyet ve zorunluluk gibi yakın anlamlar etrafında dönmektedir. ${ }^{4}$

Hamd el-Kûzî tarafından Ma yahtemilu'ş-şi'r mine'ḍ-darûre ismiyle tahkik edilip müstakil bir eser olarak ortaya konulmuştur.

3 Araştırmaların neler olduğunu görmek isteyenler mezkûr doktora tezine bakabilirler.

4 Ḥalil b. Ahmed el-Ferâhîdî, Kitâbu'l-'ayn muretteben 'alâ ḥurûfi'l-mu'cem, thk. Abdulhamîd Hendâvî, 1. Bs (Beyrut: Dâru'l-Kutubi'l-'İlmiyye, 2003), "eḍ-ḍarûra", 3/14; Ebu Bekr Muhammed b. Hasen İbn Dureyd, Kitabu 
Zarûret kelimesinin terim anlamına gelince; nahiv âlimleri, bu kelimenin ne olduğunu tam olarak ortaya koymada ittifak etmemişlerdir. Bunun sebebi her birinin zarûretten anladığı şeyin ve bunu şiirde tatbik etmedeki metodunun farklılığından kaynaklanmaktadır. ${ }^{5}$ Büyük dil bilimci el-Ferâhîdî'ye kadar zarûret kelimesinden neyin kastedildiği tam olarak bilinmemiştir. $\mathrm{O}$, eserinde şiir dilinin kendine has tabiatına işaret ederek şunları zikretmiştir:

"Şairler kelamın emirleridirler. İstedikleri yere çevirirler. Başkalarına câiz olmayan; mananın itlâkı, takyîdi, lafzı tasrif etme, düğümleme, maksûru uzatma, memdûdu kasretme, (kelamın) dillerinin arasını toplama, sıfatlarını ayırma, dillerin onu vasıflamaktan ve nitelemekten aciz kaldığı, zihinlerin de onu anlamak ve açıklamaktan aciz kaldığı şeyi ortaya çıkarma gibi şeyler onlar için câizdir..." 6

O, bu sözleriyle şiir dili ile nesir dili arasındaki farkı ortaya koyarak zarûret olgusunu bir asla bağlamıştır.

el-Ferâhîdı̂’nin zarûret olgusu hakkında ortaya koyduğu bilgiler daha sonra gelenler için önemli bir kaynak oluşturmuş ve onların şiir dili hakkında daha fazla ilerlemelerini sağlamıştır.7 Tedvin dönemi ve nahiv kitaplarının yazılmasından sonra hicri ikinci asırda zarûret mefhumu gelişim göstermiştir. Bu da Sîbeveyhi, Müberred, İbnu's-Serrâc ve İbn Cinnî (öl. 322/934) gibi nahiv âlimlerinin bu kavram hakkındaki tasavvurları sayesinde olmuştur. İlk dönem nahiv kitaplarına bakıldığında zarûret terimini açık bir şekilde kullanan ilk dil bilimcinin Müberred olduğu görülmektedir. Nitekim el-Muktadab isimli eserinde zarûret konusunu ele alırken: الضرورة لا تُجَوِّز اللحنَ "Zarûret hatayı mübah kılmaz” söyleyerek bu kelimenin terim anlamını kastetmiştir. ${ }^{8}$ Daha sonraki dönemlerde nahiv kitaplarında bu

Cemhereti'l-lugga, thk. Remzî Munîr Ba'lbekkî, 1. Bs (Beyrut: Dâru'l-'illm li'l-Melâyîn, 1987), "eḍ-ḍarûra", 1/122; Muhammed b. Ahmed el-Ezherî, Tehż̂̂bu'l-luğa, thk. Abdusselam Muhammed Harun (Şebeketu'l-Fikir, t.y.), "ḍarra", 11/458; İsmâil b. Hammâd el-Cevherî, Tâcu'l-lugia ve șihâhhu'l-'Arabiyye, thk. Ahmed Abdulğafûr 'Atâr, 4. Bs (Beyrut: Dâru'l-'Ulûm li'l-Melâyîn, 1990), “ḍarar”, 2/720; Ebu'l-Faḍl Cemaluddin el-Enșârî İbn Manzûur, Lisânu'l-'Arab (Beyrut: Dâru Șâdir, 1967), "ḍarar", 4/483-484; Muhammed b. Muhammed el-Murtazâ Zebîdî, Tâcu'l-'arûs min cevâhiri'l-kâmûs, thk. Ali el-Hilâlî, 2. Bs (Kahire: Matba'etu Hukûmeti'l-Kuveyt, 1987), "eḍḍarar", 3/349; el-Bustânî Butrus, Muhîtu'l-muhît kậmûs muṭavval li'l-luğati'l-'arabiyye (Beyrut: Mektebetu Lübnan, 1977), “ḍarar", 533; İbrahim Mustafa vd., el-Mu'cemu'l-vesît (Misır: Dâru'd-Da've, 1960), "eḍ-ḍarûra", 538.

5 Bâsil Miftâh Ali ed-Delâbîc, Eseru şâhidi'ḍ-ḍarûreti'ş-şi'riyye fi mesâili'l-ḩilâfi'n-naḥvî dirâse vașfiyye tahlîliyye (İrbid: Cami'etu'l-Yermûk, Doktora Tezi, 2016), 8.

6 Ebû İshâk el-Husrî el-Kayravânî, Zehru'l-âdâb ve s_emeru'l-elbâb, thk. Muhammed Ali el-Becâvî (Kahire: Dâru İhyâi'l-Kutubi'l-'Arabiyye, 1953), 2: 2/633; Ebu Hasan Hazim Kartâcennî, Minhâcu'l-buleġâ ve sirâcu'l-udebâ, thk. Muhammed Habîb İbn Hûce, 2. Bs (Beyrut: Dâru'l-Ğarbi'l-İslâmî, 1981), 123-124.

7 Sâmî 'İved, “Mefhûmu'ḍ-ḍarûreti'ş-şi' riyye 'inde ehemmi 'ulemâi'l-'arabiyye ḥattâ nihâyeti'l-ḳarni'r-râbi'i'lhicrî”, Mecelletu Dirâsât fi'l-luğati'l-'arabiyye ve âdâbihâ, Suriye, 6 (2011): 60.

8 Ebu'l-'Abbâs Muhammed b. Yezîd el-Müberred, el-Muktaḍab, 1. Bs (Kahire: Vezâretu'1-Evkâf, 1994), 3/354. 
kelime çokça zikredilmeye başlamıştır. Bunun sonucunda zarûret kelimesi için şiir dilini nesir dilinden ayıran şiir özelliklerini ifade etme bağlamında el-ḩurûc mine'l-ḳâ'ide(الخروج من القاعدة), eş- şuzِûz(الثذوذ), el-'udûlu'n- naḥvî (العدول النحوي), er-ruhasu'ş-şi' riyye(الرخص الثعرية), el-cevâzâtu'ş-şi'riyye(الجوازات الشعرية), el-icâzâtu'ş-şi'riyye(الإجازات الشعرية) ve benzeri kavramlar ortaya çıkmıştır. ${ }^{9}$

Dil bilginleri, kendi görüş ve kıyaslarına aykırı olan şiir beyitlerini kendi ölçütlerinin içine koymak için te'vil yoluna gitmişlerdir. Bu kural dışı beyitler nahiv âlimlerinin te'vil ve delilleri için geniş bir yer kaplamıştır. Bu bağlamda nahiv ilminde birçok ihtilâf konusu meydana gelmiştir. Bir dil bilgini kendisine aykırı olarak görüpte diğer dil bilginlerinin kendisi için delil getirdiği bir beyti zarûret bâbına atmakta tereddüt etmemiştir. ${ }^{10}$

\section{Zarûret Olgusuna Yönelik Dil Bilginlerinin Yaklaşımları}

Zarûret olgusunun dil bilginlerine göre terim anlamına baktığımızda; Sîbeveyhi başta olmak üzere Sîbeveyhi'nin el-Kitab'ını şerh eden es-Sîrâfî, Rummânî, Saffâr el-Bațalyavsî, İ̉n Harûf (öl. 609/1212) ve diğerleri, zarûret mefhûmunu açık bir şekilde açılamadan bu konuyu ele almışlardır. Fakat görüşlerine bakıldığında kendilerinin tek bir tanım üzerinde ittifak etmeyip birbirlerine aykırı görüşler ortaya koyduklarını görülmektedir. Bazıları zarûretin sadece şiirde cereyan edebileceğini söylerken diğer bazıları nesirde de olabileceğini savunmaktadır. Başka bir yönden de bazı dil bilginleri, zarûretin ancak şairin başka bir çıkış yolu bulmaması durumunda olacağını savunurken bazıları da çıkış yolu olsun veya olmasın zarûretin olabileceğini söylemiştir. Zarûret hakkında ihtilâflı birçok görüşün söz konusu olduğunu görülmektedir. Bu konuda yazılmış eserlere ve görüşlere göre genel olarak aşağıda aktarıldığı şekilde dört farklı görüşün olduğunu söylemek mümkündür.

\section{1. İbn Cinnî ve Dil Bilginlerin Çoğunluğu}

İbn Cinnî ve nahiv âlimlerinin çoğunluğu, zarûret olgusunu şairin başka çıkar yolu olsun veya olmasın şiirde dil kurallarına aykırı olarak meydana gelen şey olarak görmekte olup şairin mecbur kalmasını şart koşmamışlardır. Onlara göre zarûret, şiirle ülfet

9 Sa'duddin İbrahim Mustafa, eḍ-Darûretu'ş-şi'riyye dirâse nahoìyye fì şerḥi İbn 'Aḳ̂ll (el-Alûke, t.s.), 6.

10 Halil Bunyân Ḥesûn, fi'd-Darûreti'ş-şi'riyye (Beyrut: el-Muessesetu'l-Câmi'iyye li'd-Dirâse ve'n-Neşr ve'tTevzî̀', 1403/1983), 7 . 
kurduğundan şiirde her bakımdan caizdir. ${ }^{11}$ Şiir, vezinli bir kelam olduğundan ona bir şey eklemek veya ondan bir şey çıkarmak vezinden çıkarabilir. Bundan dolayı normal kelamda câiz olmayan bir şey, şiirde vezni oluşturmak için noksan veya ziyâde gibi olgular câiz görülmüştür. ${ }^{12}$

İbn Cinnî, bu konuda cumhûrun önderi olarak kabul edilmektedir. Onun, zarûret olgusu hakkında cumhûrla aynı görüşü paylaştığı el-Ḩașâiș isimli eserinden anlaşılmaktadır. Nitekim o, şiirin kendine has özelliğine değinerek şunları söylemektedir: الثعر موضع اضطر ار "Şiir, zarûret yeri ve özür beyan etme konumudur. Şiirde çŏ̆u zaman kelimeler kendi kalıplarından tahrif edilirler. Şiirden dolayı meseller(deyimler) konuldukları kalıplardan dönüş̧ürülürler."13

İbn Cinnî, zarûret olarak kabul ettiği yerlerde "Şiir vezninde ve i'râbta bir aykırılık olmadan şairin şöyle demesi de mümkündü” sözünü çokça kullanmaktadır. Bu da onun zarûrette mecburiyeti şart koşmadığına işaret etmektedir. O, bu konuda hocası olan Ebû Ali el-Fârisî ile tam bir uyum içindedir. ${ }^{14}$

İbn Cinnî, şairin zarûrete zorunluluk hali dışında da başvurabildiğine işaret ederek

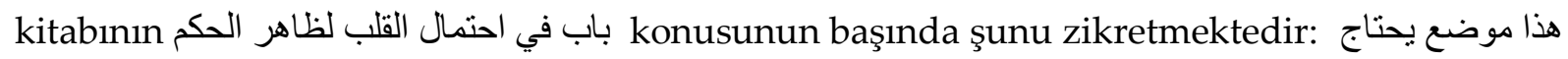
Bu, zarûret anında bir hazırlık olsun diye genişlikle beraber muhtaç olunan yerdir. "15 İbn Cinnî, bu konunun altında şairin zorunlu haller dışında zarûrete başvurduğu yerleri örneklerle açılamıştır. ${ }^{16}$ Başka bir yerde de Arapların bir zorunluluk olmadan normal durumda da zarûrete alışık olduklarına dikkat çekerek şunları dillendirmektedir: "Araplar zarûrete olan ünsiyetlerinden, alışkanlıklarından ve ihtiyaç anında onu kullanmak için bir hazırlık olsun diye normal durumda da şiirde zarûrete bağglıdırlar."17 İbn Cinnî, bu sözünün devamında zikrettiği şeye delil olarak aşağıdaki beyti getirerek şunu ifade etmiştir:

\footnotetext{
11 Ali b. Mu'min İbn 'Usfûr, el-Mukarrib, thk. Abdullah el-Cebûrî, el-Cevârî Ahmed Abdussettar, 1. Bs (Bağdad: Menşûrâtu Riâseti Divâni'l-Evkâf, 1972), 2/202; Ali b. Mu'min İbn 'Ușfûr, Darâiru'ş-şi'r, thk. Seyyid İbrahim Muhammed, 2. Bs (Beyrut: Dâru'l-Endelüs, 1982), 13.

12 Ebû Seî̀d Ḥasen b. Abdillâh es-Sîrafî, Ḍarûretu'ş-şi'r, thk. Ramaḍan Abduttevvâb (Beyrut: Dâru'n-Nehḍati'l'Arabiyye, 1985), 34.

13 Ebu'l-Feth Osman İbn Cinnî, el-Hasâiiṣ, thk. Muhammed Ali en-Neccâr (Kahire: el-Mektebetu'l-'İlmiyye Dâru'lKutubi'l-Mișriyye, t.s.), 3/188.

14 Cevâd Ḥusnî Abdurrahim, "Mevḳifu İbn Cinnî mine'ḍ-ḍarûrâti'ş-şi'riyye”, Câmi'etu'd-Duveli'l-'Arabiyye-elLisânu'l-'Arabî, 21 (1983): 38.

15 İbn Cinnî, Hașâiș, 3/59.

16 İbn Cinnî, Haṣâiș , 3/59-61.

17 İbn Cinnî, Haṣâiș, 3/303.
} 


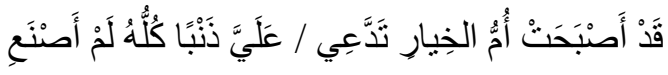

“Ummu'l-Hiyâr benim hiçbirini/bazılarını yapmadığım günahı, yaptı̆̆ımı iddia eder oldu"

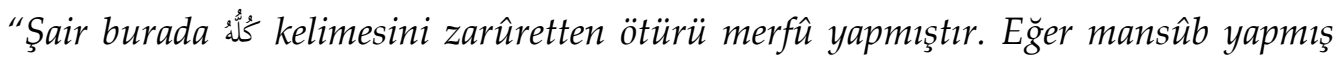
olsaydı(ki bu da kaidelere uygun olurdu) şiir vezni kırılmazdı. Bunun gibi çok örnek vardir." 18

İbn Cinnî'ye göre Araplar, zarûreti terk etmeye güçlerinin olmasına rağmen zarûreti kullanmaktadırlar. İki veya daha çok yöne muhtemel olan bir şeyin zayıf yönünü kullanmayı câiz görmelerinin bunun delili olduğunu zikretmiştir. Ona göre bir kıyas, bir neticeye götürürse ve daha sonra Arapların bu kıyasın götürdügü şeyin hilafına farklı bir şekilde o kelimeyi kullandıkları görülürse kıyasın götürdüğü şeyin terkedilip Arapların kullandığ1 şekle dönülmesi gerekir. ${ }^{19}$ Yani Araplardan duyulan bir şey, kıyasa uygun olan şeyden daha evlâdır. İbn Cinnî, şairin zarûrete başvurmasını onda bir zayıflık ve dilinde bir kusur olarak görmemektedir. Şair çirkin görse bile o zarûreti bilinçli bir şekilde kullanabilir. ${ }^{20}$ İbn Cinnî, zarûrete başvuran şairleri kendilerindeki cevherleri ortaya çıkaran yiğit ve cesur kişilere benzetmiştir. Ona göre şair bir zorunluluktan dolayı zarûrete başvurmamıştır. O, başına gelebilecek durumları bilmesine rağmen kendisinin asilliğini ve ilminin kuvvetini ortaya koymak için bunları yüklenmiştir. Bu da onun bilinçli olarak zarûreti kullandığına işaret etmektedir. Fakat İbn Cinnî bu sözünden sonra şairin zihninde mananın açık olmasının, onun bilinçsizce zarûrete başvurmasına sebep olduğunu zikretmektedir. ${ }^{21}$

İbn Cinnî, zarûret ile hatayı birbirinden ayırmaktadır. Ona göre kendisine kıyas edilmeyen ve Araplardan işitilmeyen her şey hata bâbındandır. ${ }^{22}$ Bununla beraber hata ile zarûretin arasını ayırmak için birçok bâb konusu da oluşturmuştur. Nitekim mezkûr eserinde Arapların galatları hakkındaki bab” bir konu başlığı açmış ve burada Arapların yanlışlarına birçok örnek vermiştir. ${ }^{23}$ Bu konunun devamında da باب في سَفَكَات العلماء

18 İbn Cinnî, Hașaîs, 3/303-304.

9 İbn Cinnî, Hașâis, 1/125-126, 3/60-61.

20 İbn Cinnî, Huașâis, 2/392.

21 İbn Cinnî, Hașâiș, 2/393

22 Cevâd Husnî Abdurrahim, "Mevkifu İbn Cinnî mine'ḍ-ḍarûrâti'ş-şi'riyye", Câmi'etu'd-Duveli'l-'Arabiyye-elLisânu'l-'Arabî, 21 (1983): 39.

23 İbn Cinnî, Hasâaiș, 3/273-282. 
"Âlimlerin yanlışa düştükleri şeyler hakkındaki bab" isminde bir konu başlığı da açmıştır. Bu başlıkta bu konuyu genişçe ele almıştır. ${ }^{24}$

ليس شيء يضطرون إليه إلا وهم يحاولون به وجها İbn Cinnî’nin zarûret anlayışı, Sîbeveyhi'nin "Şairlerin mecbûr kaldığı hiçbir şey yoktur ki onunla bir (dilsel)veçhi ortaya koymaya çalışmasınlar"25 sözüyle benzerlik arz etmektedir. Genel olarak İbn Cinnı̂’ye göre şairi zarûrete iten sebepleri üç noktada toplayabiliriz. Bunlar:

1- İhtiyaç anında zarûreti kullanmak,

2- Şairin yanında mananın açık olması ve karışıklığın olmaması,

3- Şairin ilmini ve cesaretini ortaya koyması.

Zarûret olgusu hakkında İbn Cinnî ile Álem eş-Şentemerî (öl. 476/1084), Radî elEsterâbâdî (öl. 688/1289), Ebû Hayyân, Cemâluddîn İbn Hişâm (öl. 761/1360) ve Abdulkadir el-Bağdâdi (öl. 1093/1682) gibi birçok dil bilimci aynı görüşü paylaşmaktadırlar. ${ }^{26}$ Zarûret olgusu hakkında savunulan bu görüşte "şiirin kendisi bir zarûrettir" diyen İbn 'Usfûr gibi bazı dil bilginlerinin aşırıya gitmelerine rağmen bu görüş İbn Cinnî’ye nispet edilmiştir. ${ }^{27}$

\subsection{Sîbeveyhi}

Sîbeveyhi, zarûretin açık bir şekilde bir tanımını yapmamıştır. Sadece kitabında bazı konuları işlerken bu konu hakkındaki bazı ibarelerle yetinmiştir. Kitabında bizzat zarûret lafzı bile geçmemiştir. Fakat bazı nahiv ve sarf kavramlarına dolaylı işareti gibi²8 zarûretin varlığını da işaret eden birtakım olgulara yeri geldiğinde dikkat çekmiştir. el-Kitâb'1 şerh eden ve inceleyen dil bilginleri ve araştırmacılar da buradan hareketle Sibeveyhi'nin yanında zarûretin mahiyetini ortaya koymaya çalışmışlardır. Bundan dolayı da bu araştırmacılar Sîbeveyhi'nin bu sözlerinden hareketle onun zarurete ilişkin görüşü hakkında ihtilâf etmişlerdir. Bazıları Sibeveyhi'nin Cumhur'un görüşünde olduğunu yani zarûret olgusunu şair için bir çıkar yol olsun veya olmasın düz yazıda benzerinin bulunmadığı şeyin

24 İbn Cinnî, Haṣâiș, 3/282-309.

25 Ebû Bişr 'Amr b. Osman Sîbeveyhi, el-Kitâb, thk. Abdusselam Muhammed Harun, 3. Bs (Kahire: Mektebetu'1Hâncî, 1988), 1/32.

26 Suleyman b. İsa el-A'lem eş-Şentemerî, Tahșîlu 'ayni'z-Zूeheb min ma'deni cevheri'l-edeb fî 'ilmi mecâzâti'l-'Arab, thk. Zuheyr Abdulmuhsin Sultan, 2. Bs (Beyrut: Muessesetu'r-Risâle, 1994), 86; İbn 'Usfûr, Darâiru'ş-şi'r, 13; Celâluddîn Abdurrahmân es-Suyûtîi, Hem'u'l-hevâmi' fì şerhi Cem'i'l-cevâmi', thk. Ahmed Şemsuddin, 1. Bs (Beyrut: Dâru'l-Kutub'il-'İlmiyye, 1998), 3/235; Abdulkadir Bağdâdî, Hazânetu'l-edeb ve lubbu lubâbi lisâni'l'Arab, thk. Abdusselâm Hârûn, 4. Bs (Misır: Mektebetu'l-Huâncî, 1997), 1/31-33.

27 Muhammed Hammâse Abdullatîf, Luġatu'ş-şi'r: dirâse fi'ḍ-ḍarûreti'ş-şi'riyye (Kahire: Dâru'ş-Şurûk, 1996), 98-99.

28 Rıfat Akbaş, Arap Gramerinde Kavram ve Terminoloji Sorunu, (Ankara: Gece Akademi Yayınları, 2018), 112-113. 
şiirde kıyasa muhalif olarak meydana gelen şey olarak gördüğünü ileri sürerken, diğer bazıları da Sîbeveyhi'nin zarûreti şair için başka çıkar yol olmadığı şey olarak gördüğünü dile getirmişlerdir. ${ }^{29} \mathrm{Bu}$ ihtilâfın sebebi her bir araştırmacının Sibeveyhi'nin sözlerinden anladığı şeyin farklı olmasından ötürüdür.

Sîbeveyhi, el-Kitab isimli eserinin ما يَحتمل الشعر bâb başlığının başında zarûret olgusuna dikkat çekerek şunları söylemiştir:

“Bil ki: munsarıf olan kelimenin isim olması gibi gayrı munsarıfın da isim olması hasebiyle isimlerden munsarıf olanına teşbih ederek gayrı munsarıf bir kelimeyi munsarıf yapmak ve hazfedilip mahzûf olarak kullanılan şeye teşbih ederek hazfedilmeyen bir şeyi hazfetmek gibi düz yazıda câiz olmayan bir şey şiirde câiz olur." 30

Sîbeveyhi, eserinde şiirde vuku bulan zarûret olgusu hakkında açık bir şekilde bâb başlığı olarak farklı yerlerde toplamda üç yerde değinmiştir. Fakat Sîbeveyhi'nin zarûret hakkındaki tutumunu belirleyen bazı yerler de vardır. Eserinin yaklaşık seksen beş farklı yerinde şiir zarûreti meselesine değinmiştir. ${ }^{31}$ Başlık olarak zarûret olgusunu konu aldığı bu üç yerin birincisi yukarıda zikrettiğimiz ما بَحتمل الثُر konusudur. İkincisi باب ما رخَّمت الثعر اءُ "Şairlerin zarûretten dolayı nidâ dışında tarhîm/ الترخي غير النداء اضطرارًا üçüncü yer ise هذا باب ما يجوز في الثعر من إيا ولا سجوز في الكلام "Bu, düz yazıda câiz olmayıp ta şiirde câiz olan إٍِّ nın kullanımı bâbıdır" konusudur. ${ }^{33}$ Sîbeveyhi, bu bâblarda zarûretin tüm unsurlarına değinmemiş olup sadece nahiv konularını anlatırken o konuya muhalif olarak şiirde ortaya çıkan kullanımlara örnek vermekle yetinmiştir.

Sîbeveyhi'nin zarûret mefhumu hakkındaki tutumu, kitabının birçok yerinde şiirde geçen şeyin dil kurallarına uyup uymadığı yani zarûret mi olduğu hususu, şiir istişhâdı yerlerinde açık bir şekilde görülebilmektedir. ${ }^{34}$ Sîbeveyhi'ye göre şair, dil dairesi dışına çıkamaz. Onun kullandığı tabir veya lafız her ne kadar kuraldışı görünse de illa Arapça dilinde bulunan başka bir kullanımına uygundur. Eğer şair dil dairesi dışına çıkıp dilde olmayan bir kullanım içine girerse bu ne şiirde ne de normal kelamda câiz olmayan hata

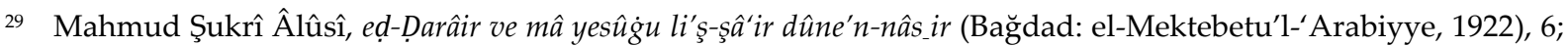
Abdullaṭ̂if, Luğatu'ş-şi'r, 90; İbrâhîm Hasan İbrâhîm, Sîbeveyhi ve'ḍ-ḍarûretu'ş-şi'riyye, 1. Bs (Kahire: Maṭba'atu Hassan, 1983), 35.

30 Sîbeveyhi, Kitâb, 26.

${ }^{31}$ M. Faruk Toprak, "Zarûrât-1 şi' riyye", Türkiye Diyanet Vakfi İslâm Ansiklopedisi (139, erişim: 29 Mart 2020).

32 Sîbeveyhi, Kitâb, 2/269.

33 Sîbeveyhi, Kitâb, 2/362.

34 Sîbeveyhi, Kitâb, 1/48, 1/85, 2/362.
} 
kabilinden bir kullanımdır. ${ }^{35}$ Sîbeveyhi, önceden de değindiğimiz gibi zarûret olgusu için açık bir tarifte bulunmamış ve zarûretlerin neler olduğu hakkında bir şey zikretmemiştir. Kendisi de bunu kitabında bizzat itiraf ederek şunları söylemiştir: وما يجوز في الثعر أكثر من أن أذكره للك هنا ؛ لأن هذا موضع جُمَلٍ سنبيِّن ذلك فيما يُستقبل إن شاء الله zikrettiğimden daha çoktur. Çükü bu, bazı konuların yeridir. Inşaallah daha sonra bunu açıklayacă̆ım"36 fakat Sîbeveyhi şiirde câiz olan kullanımların neler olacağını açıklama gayesine rağmen sözünü gerçekleştirmeden gençliğinin baharında vefat etmesi sebebiyle vaadini yerine getirememiştir. ${ }^{37}$ Daha sonraki dil bilginleri de Sîbeveyhi'nin eserinde zarûret hakkındaki sözlerinden hareketle onun bu konudaki görüşünü ortaya koymaya çalışmışlardır. Bunun sonucunda iki ayrı görüş ortaya çıkmıştır. Aşağıda da bu iki görüşü ele almaya çalışacağı:

Birinci görüş: Sîbeveyhi'ye göre zarûret olgusunun منا ليس للثناعر عنه مندوحة "Şair için başka çıkar yol olmayan şey" şeklinde olmasıdır. Saffâr el-Bațalyavsî, Ebû Hayyân, İbnu'tTayyîb eş-Şarḳî el-Fâsî (öl. 1170/1756), Muhammed Selim Efendi, Hammâse Abdullatif gibi dil bilginleri, Sîbeveyhi'nin zarûreti, şairin mecbur olması şartıyla câiz olmayan bir şeyi câiz olan bir şeye teşbih etmek veya fer' olan bir şeyi asıl olana döndürme olarak düz yazıda câiz olmayan bir şeyin şair için câiz olması şeklinde gördüğünü savunanlardandır. ${ }^{38}$

Dil bilginlerin Sîbeveyhi hakkında söyledikleri sözlerden hareketle Sîbeveyhi'ye göre zarûret olgusu; "normal kelamda câiz olmayan bir şeyin şair için iki şartla câiz olması" şeklinde bir çıkarımda bulunabiliriz. Burada aranan iki şart da şairin mecbur kalması ve bu kuraldışı kullanımın ya fer' olan bir şeyi aslına döndürmek veya câiz olmayan bir şeyi câiz olan bir şeye teşbih etmek veya illet ya da kıyas yönlerinden bir yönü araştırma yollarından bir yolla olması şeklindedir. ${ }^{39}$ Sîbeveyhi'nin şairin mecbur kalmayıp ta sadece şiir de varid olan kuraldışı kullanımlar için يجوز في الثعر "şïrde câiz olur" tabirini kullandığ1 görülmektedir. ${ }^{40}$

35 Sîbeveyhi, Kitâb, 2/385; Seyyid İbrâhim Muhammed, eḍ-Darûretu'ş-şi'riyye: dirâse uslûbiyye (Beyrut: Dâru'lEndelüs, 1983), 13.

36 Sîbeveyhi, Kitâb, $1 / 32$.

37 Nitekim racih görüşe göre Sîbeveyhi otuz üç yaşındayken Hakk'ın rahmetine kavuşmuştur. bk. Muhammed b. Hasan ez-Zubeydî, Ṭabakâtu'n-nahviyyîn ve'l-lugiaviyyîn, thk. Muhammed Ebu'l-Faḍl İbrâhîm, 2. Bs (Kahire: Dâru'l-Me'ârif, 1984), 72. .

38 Ebû Ḥayyân el-Endelüsî, İrtişâfu'ḍ-ḍarab min lisâni'l-'arab (ciltleri birleştirilmiş hali), thk. Receb Osman Muhammed, Abduttevvâb Ramazân, 1. Bs (Kahire: Mektebetu'l-Ĥancî, 1998), 5/2377; Muhammed Selîm b Ḥuseyn Abdulhalîm, Mevâridu'l-beșâir li-ferâidi'd-darâir, thk. Hâzim Se'îd Yûnus (Ammân: Dâru Ammâr, 2000), 60; Âlûsî, Darâir, 6; Abdullațîf, Luğatu'ş-şi'r, 92, 116.

39 'İved, "Mefhûmu'ḍ-ḍarûreti'ş-şi' riyye", 65.

40 Abdullaṭ̂f, Luğatu'ş-şir'r, 93. 
İkinci görüş: Sîbeveyhi'ye göre zarûret olgusunun ماوقع في الثعر دون النثر سواء أكان للثاعر “Düz yazıda değil de şair için çıkar yol olsun veya olmasın şiirde vuku bulan şeydir” şeklindeki yaklaşımdır. Bu görüşte olanlara göre Sîbeveyhi'nin zarûret hakkındaki tutumu cumhûr ulemânın tutumuyla paralellik arz etmektedir. ${ }^{41}$ Sîbeveyhi'nin bu görüşte olduğunu savunan çağdaş araştırmalardan bazıları İbrâhîm Hasan (öl. 1968) ve Hatice el-Hadîsî’dir (öl. 2018). İbrâhîm Hasan, eserinde Sîbeveyhi'nin cumhûr ulemayla aynı görüşte olduğunu açık ve kesin bir dille ifade etmektedir. Onun bu konudaki delilleri şunlardır:

Sîbeveyhi, zarûret hakkında konuşurken "Bil ki normal kelamda câiz olmayan bir şey şiirde câiz olur" demiştir. Fakat şiirdeki bu cevâzı şairin başka çıkar yolu olmamasıyla kayıtlamamıştır.

Sîbeveyhi'nin şiir zarûreti için delil olarak getirdiği birçok istişhâdı zarûret olmaktan çıkaran farklı rivayetler de vardır.

Sîbeveyhi'nin zarûret kısımlarında zikrettiği şiirlerde geçen çoğu istişhâd, kendisinde yapılacak az bir değişiklikle mana veya şiir vezninde hiçbir bozulma olmadan zarûret olmaktan çıkar. Bu da şairin başka çıkar yol olduğu halde böyle bir kullanıma gittiğine işarettir.

Sîbeveyhi, şiirlerde câiz olarak görülen şeylerin mesellerde/deyimlerde de câiz olduğu görüşündedir. Deyimlerde ne bir mecburiyet ne de bir zarûret vardır. Durum böyle olunca nasıl olur da Sîbeveyhi' nin, zarûreti şair için başka çıkar yol olmadığı olarak gördüğü söylenebilir.

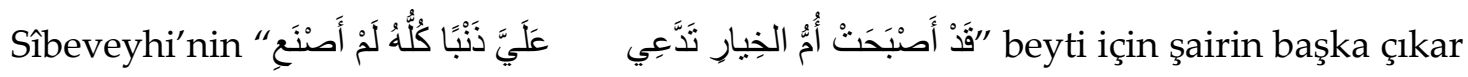
yolu olduğu için zarûret değil de düz yazıdaki gibi zayıflıkla niteleme yorumuna gelince o, bu beyitten sonraki aynı durumdaki diğer beyitler için bu sözünden geri dönmüştür. Şair için başka çıkar yol olmasına rağmen zarûret olarak nitelemiştir. Kaide gereği; bir âlimin bir konu için iki aykırı görüşü olduğu zaman en sondaki görüşüne bakılır. ${ }^{42}$

Hatice el-Hadîsî de eş-Şâhid ve ușûlu'n-nạ̣v isimli eserinde İbrâhîm Hasan ile aynı görüşü paylaşmıştır. Ayrıca Sîbeveyhi'nin bizzat örneklerinden kendisine delil getirmiştir. Örneğin; Sîbeveyhi zarûret hakkında konuşurken şairin buna mecbur olmasına işaret

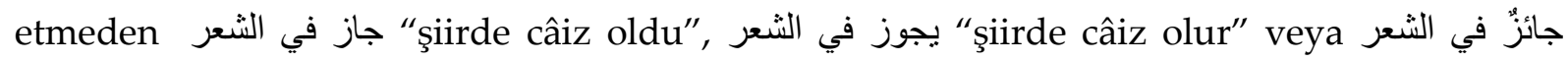
"şiirde câizdir" gibi zorunluluk manasını vermeyen tabirler kullanmıştır. Yine aynı şekilde

41 İbrâhîm, Sîbeveyhi ve'ḍ-ḍarûre, 35.

42 İbrâhîm, Sîbeveyhi ve'ḍ-ḍaûre, 41-46. 
Sîbeveyhi bazen böyle kuraldışı kullanımların düz yazıda da olduğunu fakat zayıf ve kabih bir kullanım olduğu lakin şiirde bunun câiz olduğuna işaret etmiştir. Bu da bir zorunluluğun olmadığına işaret etmektedir. Fakat şairin mecbur kaldığ1 durumlar için وإن اضطرّ شاعر veya "şair mecbur kalırsa” tabirini kullanmıştır. el-Hadîsî, bütün bunların Sîbeveyhi'nin zarûreti şair için bir zorunluk olsun veya olmasın şiirde vukû bulan şey olarak gördügüne işaret ettiğini ifade etmiştir. ${ }^{43}$ Hâlid Abdulkerîm Cum’a (öl. m. 2013) da el-Hadîsî’yle aynı görüşü paylaşmıştır. ${ }^{44}$

Tüm bu görüşlere bakıldığında bize göre Sîbeveyhi'nin zarûret hakkındaki görüşü her ne kadar ilk dönem âlimlerin görüşüne daha yakınsa da kesin bir şekilde Sîbeveyhi'ye bir görüşü nispet etmek mümkün değildir. Her iki görüşe de muhtemeldir. Bunun sebebi Sîbeveyhi'nin bu konuyu belli bir konu olarak bizzat ele almamasındandır. Sîbeveyhi zarûret ile alakalı konuları şiir ile düzyazıdaki farkı ortaya koymak için ele almıştır. Onun amacı zarûreti tüm yönleriyle ele almak değildir. Bundan ötürü görüşleri hakkında birbirine aykırı görüşler ortaya çıkmıştır.

Son olarak Sîbeveyhi'nin eseri incelendiğinde bu eserde geçen zarûretlerin dört noktada toplandığı görülmektedir. Bu noktalar şunlardır:

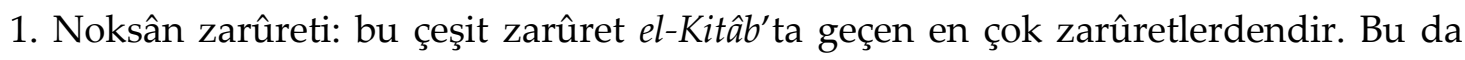
kendi içinde hareke noksanlığı, harf noksanlığı ve kelime noksanlığı diye üçe ayrılır.

2. Ziyâde zarûreti: bu zarûret çeşidi de kendi içinde hareke ziyâdeliği, harf ziyâdeliği ve kelime ziyâdeliği olarak üçe ayrılır.

3. Takdîm ve ta'hîr zarûreti: bu da bir harfin başka bir kelimenin veya bir cümlenin başka bir cümlenin önüne geçmesi gibi kullanımları kapsamaktadır.

4. İbdâl zarûreti: bu zarûret çeşidi de kendi içinde bir harfin başka bir harfle, bir kelimenin başka bir kelimeyle ve bir hükmün başka bir hükümle değiştirilmesi gibi konuları ele alır. ${ }^{45}$

\section{3. İbn Mâlik}

Sîbeveyhi'den sonra nahiv ilminde ikinci imam olarak kabul edilmesi ve dil alanında başlı başına bir ekol olması hasebiyle İbn Mâlik'in zarûret olgusu hakkındaki görüşünü tek

43 Hatice el-Hadîsî, eş-Şâhid ve uș̂ulu'n-nahv fî Kitâbi Sîbeveyhi (Kuveyt: Matbû'atu Câmi'eti Kuveyt, 1974), 305314.

44 Hâlid Abdulkerîm Cum'a, Şevâhidu'ş-şi'r fì Kitabi Sîbeveyhi, 1. Bs (Kuveyt: Mektebetu Dâri'l-'Arûbe, 1980), 347.

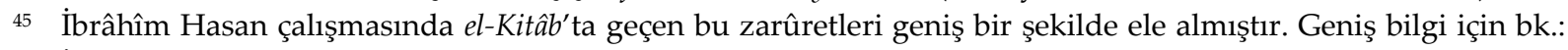
İbrâhîm, Sîbeveyhi ve'ḍ-ḍarûre, 46-340. 
olarak incelemek gerekir. İlk dönem dil bilginlerinin Sîbeveyhi'nin zarûret konusundaki görüşü hakkındaki tutumlarına paralellik arz ettiği için İbn Mâlik'in bu konudaki görüşünü Sîbeveyhi'nin görüşünün hemen ardında zikrediyoruz. Nitekim çağdaş araştırmacıların çoğu Sîbeveyhi ile İbn Mâlik'in görüşlerini bir arada vermektedirler. Örneğin Muhammed Hammâse Abdullatif Luğatu'ş-şi'r isimli eserinde zarûret olgusu hakkında dil bilginlerin görüşlerini ortaya koyarken ilk görüş olarak رأي سييويه وابن مالك "Sîbeveyhi ve İbn Mâlik'in görüşı̈" şeklinde beraber zikretmektedir. ${ }^{46}$

İbn Mâlik'e göre zarûret kelimesi, zorunluluk ve mecburiyet anlamında olan ضرر kelimesinden türediğinden zarûret olgusu ما ليس للثناعر عنه مندوحة "Şair için başka çıkar yolun olmadığg şeydir." 47 Bundan ötürü zarûret olgusu, şairin ancak mecbur olduğu durumda zarûret gerçekleşir. Eğer mecbur olmadığı halde kuraldışı kullanım yaparsa bu zarûret değil de ihtiyâr olur. ${ }^{48}$ İbn Mâlik, bu görüşüyle zarûret olgusunun alanını baya daraltmıştır. Çünkü o, zarûreti mecburiyet ve zorunluluğa bağlamıştır. Şairin, eğer şiir vezninde veya kafiyesinde bir bozulma olmadan kullandığı kuraldışı kelimeye denk olan dil kurallarına uygun başka bir kelime getirebilme imkânı varsa bu zarûret olmaz.

İbn Mâlik'in şiirdeki kuraldışı kullanımları ikiye ayırdığı görülmektedir;

1. Şairin değiştirmesine imkân bulamadığı yani mecbur kaldığı şey olup bu da sadece şiirde câiz olur.

2. Başka bir kelimeyle değiştirilme imkânı olan yani şairin o kullanım için mecbur kalmadığı şey ise şiire has olmayıp ihtiyârda yani düz yazıda da câiz olup buna zarûret denilmez. ${ }^{49}$

Her ne kadar dil bilginlerinin çoğuna göre Sîbeveyhi bu görüşteyse de bu görüş daha çok İbn Mâlik'e nispet edilmekte ve bu görüşe yapılan itirazlar Sîbeveyhi'ye değil de İbn Mâlik'e karşı yapılmaktadır. Neticede bu görüş nahiv âlimlerinin yanında kendisine çok destek bulamamıştır. ${ }^{50}$

46 Abdullațîf, Luğatu'ş-şi'r, 90.

47 Cemâluddîn Muhammed b. Abdillah İbn Mâlik, Şerḥu't-Teshîl, thk. Abdurrahmân Seyyid, Mahtûn Muhammed Bedvî, 1. Bs (Mısır: Dâru Hecer, 1990), 1/201-202; Bağdâdî, Hizânetu'l-edeb, 1/31; es-Suyûțî, Hem'u'l-hevâmi', 3/235; Celâluddin Abdurrahmân es-Suyûtî, el-İktirâh fî Ușûli'n-naḥv, 2. Bs (Beyrut: Dâru'1Beyrûtî, 2006), 60-61; Abdulhalîm, Mevâridu'l-beșâir li-ferâidi'ḍ-ḍarâir, 61; Âlûsî, Darâir, 6.

48 Cemaluddin Muhammed b. Abdillah İbn Mâlik, Şerḥu'l-Kâfiye eş-şâfiye, thk. Abdulmun'im Ahmed Herîrî (Mekke: Merkezu'l-Bahsi'l-'İlmî, 1982), 1/299-301; İbn Mâlik, Şerḥu't-Teshîl, 1/201-203.

49 Hadîsî, eş-Şâhid ve ușûlu'n-naḥv, 116; Abdulvehhab Muhammed Ali el-'Edvânî, eḍ-Darûratu'ş-şi'riyye dirâse luggaviyye nakdiyye, 1. Bs (Beyrut: Dâru'1-Endelüs, 1979), 132.

50 Abdullațîf, Luğatu'ş-şi'r, 94. 
İbn Mâlik'in bu görüşü kendisinden sonra gelen dil bilginleri özellikle Şâtibî (öl. 790/1388), Ebû Hayyân, İbn Hişâm ve Bağdâdî tarafından şiddetli eleştiriye maruz kalmıştır. Nitekim Celâluddîn es-Suyûtî (öl. 911/1505), Ebû Hayyân'ın İbn Mâlik'i nahiv âlimlerinin şiir zarûreti hakkındaki görüşlerini anlamayıp zarûreti 'bir şeye mecbur kalmak' şeklinde anladığını söyleyerek eleştirdiğini nakletmiştir. Çünkü hiçbir zarûret yoktur ki onu kaldırıp başka bir kullanımı getirmek mümkün olmasın. Fakat dil bilginlerinin zarûretten kasıtları onun, şiire has olan bir kullanım olmasıdır. Eğer böyle olmazsa zarûret diye bir şey olmaz. Çünkü hangi lafız olursa olsun şair, onu değiştirebilir. ${ }^{51}$ Ebû Hayyân'ın İbn Mâlik'e karşı bu eleştirisi araştırmacılar tarafından - İbn Mâlik'in özellikle dil alanında bu kadar büyük bir mertebede olup ta zarûreti kavrayamamasının mümkün olmaması, Ebû Hayyân'ın bizzat kendisinin de eserinde Sibeveyhi'nin bu görüşte olduğunu zikretmesi ve İbn Mâlik'ten önceki bazı diğer âlimlerin de bu görüşte olmasıyla beraber Ebû Hayyân'ın kalkıp sadece İbn Mâlik'i eleştirmesi ve onu bu konuyu anlamamakla itham etmesi ve onun değerini düşürmeye çalışması bakımından - eleştirilmiştir. ${ }^{52}$

İbn Mâlik'i en geniş anlamda eleştirenlerden sayılan Şatibî, İbn Mâlik'i dört konuda eleştirmektedir. Bu dört konu şudur;

1. Nahiv âlimlerinin bu görüşü itibara almamaları ve İbn Mâlik'in bu konuda bazı şeyleri ihmal ettiğine dair icmâ etmeleri.

2. Nahiv âlimlerinin yanında zarûret olgusu, zikredilen şeyin dışında başka bir kelimenin gelmesinin mümkün olmayışı anlamına gelmemektedir. Çünkü her zarûretin yerine illaki başka bir lafız getirmek mümkündür. İbn Malik'in savunduğu görüş, şiirde zarûretin olmamasına yol açar. Bu da icmânın hilafınadır.

3. Bazen aynı mana için birden fazla kelime kullanılabilir. Öyle ki o manayı ifade etmek için bu kelimelerden birini kullanmak zarûreti gerektirebilir. Fakat bu kelime muktezayı hale daha uygundur. Hiç şüphesiz ki şairler burada zarûrete başvururlar.

51 Cemaluddin Abdullah b. Yusuf İbn Hişâm, Tahlîșu'ş-şevâhid ve Telhîșu'l-fevâid, thk. Abbas Mustafa es-Sâlihî, 1. Bs (Beyrut: Dâru'l-Kitâbi'l-'Arabî, 1986), 81-82; Celâluddin Abdurrahmân es-Suyûtî, el-Eşbâh ve'n-neẓâir fi'nnahv (Beyrut: Dâru'l-Kutubi'l-'Illmiyye, t.s.), 1/268; Âlûsî, Darâir, 8; İbrâhîm, Sîbeveyhi ve'ḍ-ḍarûre, 33; Hुâlid Sa'd Şaban, Uș̂̂lu'n-naḥv 'inde İbn Mâlik (Kahire: Mektebetu'1-Ầdâb, 2009), 134.

52 el-Endelüsî, İrtişâfu'ḍ-ḍarab, 5/2377; Şaban, Uș̂̂lu'n-naḥv 'inde İbn Mâlik, 134; Abdullaṭ̂f, Luğatu'ş-şi'r, 94. 
4. Araplar, zihaf (bir kelimede harf veya harekede noksanlığa gitmek)tan ötürü kıyasa uygun kelamdan imtina edip içinde zihaf olan bir şiiri güzel görürler. Şair de bundan ötürü zarûrete başvurur. ${ }^{53}$

Hammâse, Şatibî'nin İbn Mâlik'e olan bu itirazlarına karşı İbn Tayyî̉'in İbn Mâlik'in İcmâyı delmediğini çünkü Sîbeveyhi'nin de zarûret olgusu hakkında İbn Mâlik gibi düşündüğünü ve ayrıca İbn Hâcib'in Sîbeveyhi'ye itiraz ederken onun zarûrette başka çıkar yol olmama (عدم المندوحة) şartını koyması sebebiyle değil de onun zarûretin oluşması için şart koyduğu şey cihetiyle itirazda bulunduğu şeklinde cevap verdiğini zikretmiştir. Hammâse, sözünün devamında İbn Mâlik'i eleştirenlerin onu kötülemek için itirazda bulunduklarını zikretmiştir. ${ }^{54}$ Çağdaş araştırmacılardan İbrâhîm Hasan, el-'Edvânî, Muhammed Abdulfettah el-Hatîb gibi araştırmacılar da İbn Mâlik'in zarûret olgusu hakkındaki görüşünü eleştirmişlerdir. Onlara göre İbn Mâlik'in görüşü şiirin tabiatına riâyet etmeden ve şiirin duygu ve hislerin dili olduğuna bakmadan sadece zarûret kelimesinin sözlük anlamına dayanmasından dolayı yanlıştır. ${ }^{55}$

İbn Mâlik'in bu konudaki görüşünü eleştirenler olduğu gibi cumhûr ulemânın görüşünü eleştirip İbn Mâlik'i savunanlar da var. Onlara göre cumhûr ulemâ, şiirde kendi kıyaslarına uymayan bir şey gördüklerinde ve o kullanıma doğru yön bulmaktan aciz kaldıklarında onu zarûrete hamletmişlerdir. Nazımda kendi kurallarının kabul etmediği her şeyi zarûrete hamletmek mümkündür. İster şair için bir çıkar yol olsun ister olmasın. İbn Mâlik ise zarûret olgusunu şair için başka çıkar yol bulmama kaydıyla sınırlandırmaya çalışmıştır. ${ }^{56}$

Bazı dil bilginleri de İbn Mâlik'in zarûret hakkındaki görüşünün cumhûrun görüşüne uygun olduğunu açılamaya çalışmışlardır. Onlara göre İbn Mâlik'in şairin başka çıkar yolu olmaması şartı normal durumlarda kolaylıkla akla gelebilen şeylerin olmaması anlamına gelmektedir. Yani eğer zarûret olarak kullanılan kelimenin yerine kurallara uygun başka bir

53 Bağdâdî, Hizânetu'l-edeb, 1/33-34; Âlûsî, Ḍarâir, 6-8; İbrâhîm, Sîbeveyhi ve'ḍ-ḍarûre, 33-34; 'Edvânî, eḍ-Darûratu'şşi'riyye, 141; Abdullațîf, Luġatu'ş-şi'r, 95-96; İbrahim b. Salih el-Handûd, eḍ-Darûretu'ş-şi'riyye ve mefhûmuhâ lede'n-nahoiyyîn/dirâse tațbikiyye 'alâ Elfiyyeti İbn Mâlik (Medine-i Münevvere: el-Câmi'etu'l-İslamiyye, 2001), 10-11; Ali Abdullah Ḥuseyn el-`Enbekî, “Mefhûmu'ḍ-ḍarûreti'ş-şi'riyye 'inde İbn Malik”, Mecelletu'l-ustâz, Cami'etu Diyâlâ, Irak, 205 (1434 2013): 175-176.

54 Abdullațîf, Lugiatu'ş-şi'r, 96.

55 İbrâhîm, Sîbeveyhi ve'ḍ-ḍarûre, 32-33; el-'Enbekî, “Mefhûmu'ḍ-ḍarûreti'ş-şi'riyye”, 176-177; 'Edvânî, eḍDarûratu'ş-şi'riyye, 140, 147-148; Muhammed Abdulfettâh Hatîb, Davâbițu'l-fikri'n-nahvồ (Kahire: Dâru'l-Basâir, 2006), $1 / 482$.

56 Țaha er-Râvî, Nezarât fi'l-luġa ne'n-naḥv, 1. Bs (Beyrut: Menşûrâtu'l-Mektebeti'1-Ehliyye, 1962), 26; Abdu'1-'Âl Sâlim Mukrim, el-Medresetu'n-nahviryye fì Mișir ve'ş-Şâm, 1. Bs (Beyrut: Dâru'ş-Şurûk, 1980), 269; el-'Enbekî, “Mefhûmu'ḍ-ḍarûreti'ş-şi'riyye”, 178. 
kelime kolay bir şekilde akla hemen gelmiyorsa bu zarûret olur. Böylece ona karşı yapılan reddiyelerin ve eleştirilen bir yeri de yoktur. ${ }^{57}$

İbn Mâlik'in zarûret olarak kabul etmeyip de başkalarının zarûret olarak kabul ettiği bazı kullanımlar şunlardır:

kelimelerine mütekellim için gelen ya (ب) ليس، لبي، من، عن، قد، قط kelimeye eklenmesi gereken nun-u vikâyenin hazfi ${ }^{58}$,

ism-i işaret olan ذلكم zamirinden mim harfini hazfederek kaf harfinin damme harekesini işbâ' ile yetinip ذللٌ şeklinde okumak ${ }^{59}$,

Özel isim, hal ve temyîzin başına tarif edatı olan elif lâm'ın dâhil olmasi ${ }^{60}$,

مع kelimesinin ayn harfini kendisinden sonra gelen harf harekeliyse sâkin yapmak ve sâkinse kesralı okumak ${ }^{61}$,

ك ve temyîzinin arasını ayırmak ${ }^{62}$,

Olumlu muzâri fiiline te'kîd nûnu eklemek ${ }^{63}$,

Şart cümlesinde şart fiilinin muzâri fiil olarak, cevap fiilininde mâzi fiil olarak gelmesi ${ }^{64}$,

Bir kelimenin vasıl halini vakıf olarak okumak yani sekte için gelen hâ harfini veya başka bir ek eklemeden öylece bırakıp vakfetmek ${ }^{65}$

İbn Mâlik, çoğu zaman zarûret kelimesi yerine يجوز في الثعر "şiirde câiz olur", وقاء في "şiirde gelmiştir ki” gibi sözleri kullanmakla yetinmiştir. Bazı eserlerinde de bazı olguların düz nesirde değil de şiirde çok bulunduğuna dikkat çekmiştir. Bu da onun Sîbeveyhi'den etkilendiğine işaret etmektedir. ${ }^{66}$

\subsection{Ebu'l-Hasan el-Ahfeş}

Ahfeş (öl. 215/830), zarûret olgusu hakkında diğer dil bilginlerin görüşlerinden farklı bir tutum sergilemiştir. Öyle ki o, şairleri diğer insanlardan farklı bir konumda görmektedir.

\footnotetext{
57 Muhammed b. Ali eș-Ṣabbân, Hâş̧iyetu'ș-Șabbân 'alâ Şerḥi'l-Eşmûnî (İran: İntişâratu Zâhidî, t.s.), 1/165.

58 Cemâluddîn Muhammed b. Abdillah İbn Mâlik, Teshîlu'l-fevâid ve tekmîlu'l-mekâṣid, thk. Muhammed Kamil Berekât (Misır: Dâru'l-Kâtibi'1-'Arabî, 1968), 25.

59 İbn Mâlik, Teshîlu'l-fevâid, 40.

60 İbn Mâlik, Teshîlu'l-fevâid, 42.

61 İbn Mâlik, Teshîlu'l-fevâid, 98.

62 İbn Mâlik, Teshîlu'l-fevâid, 124.

63 İbn Mâlik, Teshîlu'l-fevâid, 216.

64 İbn Mâlik, Teshîlu'l-fevâid, 239-240.

65 İbn Mâlik, Teshîlu'l-fevâid, 331.

66 Abdullațîf, Luğatu'ş-şi'r, 97.
} 
Bundan dolayı başkalarına câiz olmayan bir şey onlara câiz olur. Şairler için tanınan bu cevâz sadece şiire has olmayıp onların şiirlerinde olduğu gibi nesirlerinde de bulunmaktadır. Şairlerin kendileri, ilk olarak şiirlerinde söyledikleri kullanımlardan etkilenip şiirde alışageldikleri bu kullanımları normal konuşmalarında da kullanırlar. Daha sonra da şairlerin kendileriyle arkadaşlık yaptıkları kişiler veya şairleri taklid edenler veya başka kişiler şairlerin bu kullanımlarından etkilenerek onlar da kendi normal kelamlarında kullanırlar. ${ }^{67}$

Ahfeş'in bu konudaki genel görüşü şudur: "Şair olmayanlar için normal kelamda câiz olmayan bir şey şair için şiirinde ve normal kelamında câiz olur. Çünkü şairin dili zarûrete alıştığından dolayı başkalarına câiz olmayan bir şey onun için câiz olur."68 Ahfeş'in zarûret hakkındaki bu görüşünden onun, hocası Halîl b. Ahmed'ten etkilendiği görülmektedir. Nitekim Halîl b. Ahmed şairlerin sözleri kelam / الكلام lafzını kullanması onun, şairler için zikrettiği şeyleri şiir ve nesir için aynı şekilde gördüğünü ima etmektedir. ${ }^{69}$

Ahfeş, bu görüşüyle başka dilbilginlerinin yanında sadece şiirde câiz olan birçok şey için açık bir ara açmıştır. Çoğu yerde normal kelamda bu tür kullanımlar için جاء هذا على لغة "Bu, şairlerinin dili üzerine gelmiştir." tabirini çokça kullanmış olup kendisinin zarûret olarak isimlendireceği kullanımları çokça azaltmıştır. Çünkü o, başkaları için sadece zarûret anında olabilecek şeyleri şairler için normal kelamlarında da câiz görmektedir. Çünkü şairler, bu tür kullanımlara çokça alışıklar.70 Ahfeş bu tür kullanımlar için lügat / اللغة tabirini kullanmaktadır. $\mathrm{Bu}$ da onun, lügatten kastının şairlerin üzerinde bulundukları dili kastettiğini ortaya koymaktadır. ${ }^{71}$

Ahfeş'in tüm bu görüşlerinden onun, dilde müsamahaya meylettiğini görmekteyiz. Onun şairler için şiirde câiz olan olguları düzyazılarında da câiz kılması zarûreti baya daraltmakta hatta zarûret olgusunu da ortadan kaldırmaktadır. Ona göre şairler, insanlardan farklı bir grup oldukları için onlar için şiir ve düzyazıda câiz olan bir şey başkaları için sadece zarûrette câiz olur. Ayrıca Ahfeşin dil alanında derin bir birikime sahip olması farklı lehçelere, Kur'ân kırâatlerine vakıf olması onun dile olan bakışını genişletmiş olup

\footnotetext{
67 Ali b. Mu'min İbn 'Ușfûr, Şerḥu Cumeli'z-Zeccâcî, 1. Bs (Beyrut: Dâru'l-Kutubi'l-'Illmiyye, 1998), 3/148; Abdullațîf, Luġatu'ş-şi'r, 105-106.

68 İbn 'Ușfûr, Şerḥu Cumeli'z-Zeccâcî, 3/148.

69 el-Ḳayravânî, Zuheru'l-âdâb, 2: 2/633; Kartâcennî, Minhâcu'l-buleg̀â, 123-124; Adil Ahmed Sâlim Bânâ'ime, eḍDarûretu'ş-şi'riyye fi'ş-şi'ri'l-ḥurr (Mekke: Câmi'etu Ummi'l-Ḳurâ, 2016), 6.

70 Abdullaṭ̂if, Luggatu'ş-şi'r, 106-107.

71 Müberred, Muktaḍab, 4/350; Abdullaṭ̂f, Luġatu'ş-şi`r, 107.
} 
başkalarının zarûret dediği şeyin benzerlerine muttali olması, kendisinin o kullanım için zarûret kelimesini kullanmasını engellemiştir. Fakat onun zarûret olgusu hakkındaki bu görüşü dil bilginleri tarafından fazla destekçi bulamamıştır. ${ }^{72}$

Bize göre bu görüş zarûret konusunda fazla geniş davranmıştır. Çünkü biz eğer başkaları için câiz olmayan bir şeyi şiirinden dolayı şair için câiz kılıyorsak bu, şairin şahsiyetinden ötürü değil de şiir dilinin özelliğinden dolayıdır. Eğer bir şair, normal düz yazı şeklinde konuşursa şiirin kıyaslarına göre değil de düz yazının ölçütlerine göre değerlendirilmelidir.

\section{5. İbn Fâris}

Zarûret olgusu konusunda İbn Fâris'in de kendine münhasır görüşü vardır. Ona göre nahiv âlimlerinin zarûret olarak isimlendirdikleri ve onun için çıkar yollar bulmaya çalışmaları hatadan başka bir şey değildir. İbn Fâris, kuraldışı kullanımlara örnek olarak ortaya koyduğu şiir beyitleri için hata yapmanın Allah (cc)'ın koruduğu peygamberler dışında tüm insanlar için normal bir şey olduğuna dikkat çekerek bu kullanımların tamamının hata ve galat olduğunu söylemiştir. ${ }^{73}$

İbn Fâris, zarûret olgusu hakkındaki görüşünü iki eserinde ortaya koymuştur. Birincisi bu konuyu ortaya koyma sebebiyle te'lîf ettiği Zemmu'l-h̆ața' fi'ş-şi'r ismini verdiği küçük bir risaledir. Bu eser, hacim olarak küçük olmasıyla beraber İbn Fâris'in zarûret olgusu hakkındaki tutumunu özetlemektedir. Bu eserde bu eseri te'lîf etme nedenini ve dil bilginlerin zarûret-i şi'riyye diye isimlendirdikleri şey hakkındaki konumunu ortaya koymuştur. ${ }^{74}$ Ona göre şair söylediklerinin çoğunda doğruyu isabet etmişlerdir. Onlardan kuraldışı kullanım olarak gelen az şeyler ise dil bilginleri tarafından zarûret olgusu bahanesi altında ele alınmıştır. Fakat bu hatadan başka bir şey değildir. ${ }^{75}$ İbn Fâris, şiirdeki vezin sebebiyle şairin zarûreti kullanması deliliyle kuraldışı kullanımları şairler için câiz kılanlara cevap olarak şunları zikretmektedir:

“Eğer deseler ki 'şair buna mecbur kalıyor çünkü o, şiirinin veznini düzeltmek istiyor. Eğer o, bunu yapmamış olsaydı şiiri düzgün olmazdı.' Onlara denilir

72 Abdullațîf, Luğatu'ş-şi'r, 107-108.

73 Ebu'l-Huseyn Ahmed İbn Fâris, es-Ṣahhibî fî fikhi'l-lugiati'l-'arabiyye ve mesâilihâ ve suneni'l-'Arab fì kelâmihâ, thk. Ahmed Hasan Besc (Beyrut: Dâru'l-Kutubi'l-'Arabiyye, 1997), 213.

74 Ebu'l-Ḥuseyn Ahmed İbn Fâris, Žemmu'l-hatạa' fi'ş-şi'r, thk. Ramazân Abduttevvâb (Mısır: Mektebetu'l-Hâncî, 1980), 17-18.

75 İbn Fâris, Zemmu'l-hața, 23-24. 
ki 'kim, onu sadece hata kullanmasıyla vezni düzgün olacak bir şiir söylemesini mecbur bıraktı? Biz, bir sultanın veya zorba birinin kılıç veya kırbaç zoruyla bir şairi câiz olmayan bir şeyi ve sizin başkasının kelamında câiz görmediğiniz bir şeyi şiirinde söylemesine mecbur bıraktığını duymadik.'"'76

İbn Fâris, bu sözüyle kendisinin şiir ve nesir dilini aynı görüp birbirinden ayırmadığını ortaya koymaktadır. Bundan ötürü o, zarûreti nesir dilinin bağlı olduğu aynı dil kuralları altında görüp şaire bu kaidelerin dışına çıkma hakkını vermemiştir.

İbn Fâris, şairin kastettiği manayı ancak zarûrete girmekle ortaya koyabildiği ve şiirini oluşturma anında gözünü bu manaya diktiği için hataya düştügünü anlamaması bahanesini kabul etmeyerek bunun daha kötü bir ayıp olduğunu ve şair düzgün bir şekilde elli beyit oluşturuyorken onun ayıplı olan bu beyitten kaçınmasını engelleyen şeyin ne olduğunu ve kaçınması durumunda bunun bir günah olmadığını veya şairin kişiliğine zarar vermediği zikretmiştir. ${ }^{77} \mathrm{O}$, bu görüşleriyle nahiv âlimlerinin inşa ettiği binayı yıkmıştır. İ̉bn Fâris'in zarûret olgusu hakkındaki bu görüşüne Ebû Hilâl el-'Askerî, Ali b. Abdilaziz elCurcânî (öl. 392/1001) gibi bazı âlimler uygunluk arz etmişlerdir.

İbn Fâris'in zarûret olgusuna değindiği ikinci yer ise eș-Ṣâhibî fî fiḳhi'l-lugga isimli eseridir. $\mathrm{O}$, bu eserinde Zूemmu'l-ḩața' isimli eserinde geçen bazı şeyleri tekrar etmiştir. Fakat bu eserinde daha yumuşak bir dil kullanmıştır. Burada da zarûreti mutlak olarak inkâr etmemekle beraber şairlerin masum olmayıp hata yaptıklarını tekrar te'yid etmiştir. Diğer eserinde zikrettiği şeyin aksine bu esrinde şairlerin kelamın emirleri olduklarını memdûd kelimeyi maksûr yaptıklarını, maksûru memdûd yapmadıklarını takdîm ve ta'hîr gibi şeyler yaptıklarını zikretmektedir. ${ }^{78}$ Her ne kadar İbn Fâris'in iki eserinde birbiriyle çelişkili ifadeler varsa da bunun sebebi İbn Fâris'in eș-Ṣâhibî fî fikhi'l-lugga eserinde şairlerin kelamın emirleri سُنن العرب في / olması gibi ifadelere vermesi Arapların kelamlarındaki takip ettikleri yollar konusu altında doğrudan zarûret konusunu ele almadan şairler için Arapların takip ettiği bu yollardan genel olarak birçok kapıyı genişçe açmış olmasıdır. Onun, önceki eserinde şairler için zarûreti mutlak olarak kabul etmemesi orada hususi bir zaviyeden bakmasından ötürüdür. Bununla beraber İbn Fâris'in bu tutumu başta kabul veya red tutumunu tutup ta

76 İbn Fâris, Zemmu'l-ḩața, 21.

77 İbn Fâris, Zemmu'l-ḩața, 21.

78 İbn Fâris, eṣ-Ṣahibî fí fikhi'l-lug̀a, 213. 
tatbikte bunun aksine muamelede bulunan birçok dilcinin yaptığ gibi bir davranış da olabilir. ${ }^{79}$

İbn Fâris eṣ-Ṣ̂hhibî fí fikhi'l-luğa eserinde zarûreti mutlak anlamda reddetmemiş ve dil bilginlerin zarûret olarak isimlendirdikleri şeyleri üç kısma ayırmıştır.

1- Memdûd kelimeyi maksûr yapmak, takdîm ve ta'hîr yapmak, ihtilâs, isti'are gibi diğer insanlara değil de sadece şairlere câiz olan kullanımlar. İ'râbta hata yapmak ve bir kelimeyi sahih kullanımından çevirmek gibi bir şey ise şairlerin böyle bir hakkı yoktur. ${ }^{80}$

2- Arap diline has özelliklerden ve sanatlarından kabul edilen kullanımlar. İbn Fâris bu tür kullanımlar için bast / البسط, kabd / القبض, idmâr / الإضمار gibi farklı isimler kullanmıştır. Onun bu tür kullanımlar için zarûret veya şiire has kullanımlar tabirini kullanmasını engelleyen şeyin onun bu tür kullanımlar için farklı lehçeleri itibare almasından ötürüdür denilebilir. ${ }^{81}$

3- Yukarıda bu konumuzun başında zikrettiğimiz gibi hata ve galat olarak kabul edilen kullanımlar.

Genel itibariyle Basra ve Kûfe ekollerinin zarûret olgusuna dair tutumlarına bakıldığında ise bu iki ekol arasında Arap dili kaidelerini ortaya koyarken oluşan ihtilafların zarûret olgusu hakkındaki tutumlarını etkilemediği görülmektedir. Sîbeveyhi'nin Basra ekolunun önemli temsilcilerinden olması hasebiyle kendisinin zarûret olgusu hakkındaki görüşü Basralı dil bilginleri temsil etmektedir demek mümkün olmadığı gibi Kûfeli dil bilginlerin birçok konuda kendisine uydukları Ahfeş'in zarûret hakkındaki görüşü ve Kûfeli dil bilginlerinden olan İbn Fâris'in görüşü de Kûfeli dil bilginlerin görüşünü temsil etmektedir demek de mümkün değildir. ${ }^{82}$

Bununla beraber zarûret mefhûmu hakkında değil de zarûreti tatbik etme konusunda Basra ve Kûfe ekolleri arasında birtakım ihtilâfların olduğu görülmektedir. Bunun sebebi de her bir ekolun kendi dil kurallarını oluştururken izlediği metottur. Bu iki ekolun zarûret olgusu hakkındaki ihtilâfları üç sınıfta toplanılabilir. Birincisi: Kûfeli dil bilginlerinin normal yazıda câiz görüp de Basralıların zarûret kabul ettikleri meseleler olup bu tür ihtilâfların çoğunun sebebi Kûfeli dil bilginlerin bir kaideyi oluştururken tek bir istişhade dayanmaları,

\footnotetext{
79 Abdulhekim Râdî, Naẓariyyetu'l-luġa fi'n-nakdi'l-'arabî dirâse fî hasâaiși'l-lugiati'l-edebiyye min manẓ̂uri'n-nukkâdi'l'Arab (Kahire: el-Meclisu'l-A'lâ li's-Sakâfe, 2003), 60-61.

80 İbn Fâris, eș-Ṣâhibî fî fikhi'l-lugga, 213.

81 Abdullaṭ̂if, Lug்atu'ş-şi'r, 111-112.

82 Abdullatîif, Luggatu'ş-şi'r, 112-113.
} 
Basralıların ise bunu kabul etmemeleri ve her birinin dil kurallarında izlediği kıyasın farklı olmasıdır. İkincisi: Kûfeli dil bilginlerinin zarûret olarak kabul edip Basralı dil bilginlerin hiçbir şekilde ne şiirde ne nesirde kabul etmedikleri meselelerdir. Bu kısmın meseleleri sınırlı sayıda ve azdır. Bu ihtilâfların sebebi de tek bir şiir istişhâdını kabul etme veya etmeme ve kıyası uygulama yöntemidir. Üçüncüsü ise Basralı dil bilginlerin şiir zarûretinde câiz görüp Kûfeli dil bilginlerin câiz görmediği meselelerdir. ${ }^{83}$

Yukarıda zikrettiğimiz meseleler görüldüğü gibi ihtilâflı konulardır. Bazı meseleler az istişhâdlere dayandığı için Basralı dil bilginleri bu delilleri eleştirmeye çalışmış olup kendi usullerini oluşturmuşlardır. Kûfeli dil bilginleri ise tek bir şiirde de geçmişse bu kullanımı câiz görmüştür. ${ }^{84}$ Zarûret olgusu hakkında zikrettiğimiz görüşlerden Sîbeveyhi(Bazı dil bilginlerine göre), İbn Mâlik, Ahfeş ve Kûfeli dil bilginlerinin görüşlerinin her ne kadar hedeflerine giden metotları farklı olsa da bu görüşlerin aynı veya yakın amaçta birbirleriyle uyuştuğunu görmekteyiz. Çünkü bu görüşlerin tamamı zarûret olgusunu dar bir alana koymaktadir.

\section{Sonuç}

Bu çalışmanın sonunda şu sonuçlara ulaşılmıştır:

Birbirinden farklı bakış açlarından ötürü dil bilginleri zarûret olgusu hakkında birbirinden farklı görüşleri savunmuşlardır.

Zarûret olgusu hakkında temelde birbirine zıt iki görüşün olduğu görülmektedir. Şairin mecbûr kalıp kalmamasına bakılmaksızın şiirde vukû bulan kuraldışı her kullanımı kabul edip zarûretin alanını genişleten görüş ile zarûreti, sadece şairin mecbûr kalmasına bağlayan görüş şeklinde iki tutum görülmektedir. Birinci görüşün temsilcileri kendisine nisbet edilen farklı iki görüşten birinin sahibi olan Sîbeveyhi ve İbn Cinnî'nin başını çektiği dil bilginlerin çoğunluğunu oluşturuyorken ikinci görüşün temsilcisi Sîbeveyhi'ye nisbet edilen görüşü benimseyen İbn Mâlik'tir.

Bunun yanında Ahfeş, şairlere has bir durum olarak zarûretin şairlerin dil alışkanlıkların ötürü normal kelamlarında da câiz olduğu görüşünü savunmakta, İbn Fâris

\footnotetext{
83 Bu iki ekol arasında zarûret olgusunun tezahür ettiği yerler hakkında bk. Kemaluddin Ebu'l-Berekât elEnbârî, el-İnșâf fî mesâili'l-ḩilâf beyne'n-nahviyyîn: el-Bașriyyîn ve'l-Kûfiyyîn, thk. Muhammed Muhyiddin Abdulhamîd (Beyrut: Dâru'l-Fikir, t.y.), 1/120-125, 1/169-176, 1/239-245, 1/247-251, 1/274-276, 1/279-281, 1/284291, 2/359-367, 2/369-373, 2/388, 2/442, 2/473-476, 2/592-593, 2/682-684.

84 Abdullaṭîf, Luggatu'ş-şi'r, 116.
} 
şiirde görülen dil kurallarına aykırı olarak görülen bu kullanımların hatadan başka bir şey olmadığını söyleyip zarûret olgusunun olmadığını öne sürmektedir.

Basralı ve Kûfeli dil bilginleri arasında zarûret olgusunun tezahür ettiği yerlerde de ihtilâflar söz konusudur. Kûfeli dil bilginlerinin semâ olgusuna Basralı dil bilginlerinden daha çok itimat etmelerinden ötürü Basralı dil bilginlerinin zarûret olarak nitelendirdikleri şiirdeki birçok kullanımın Kûfeli dil bilginleri tarafından zarûret olarak görülmediği bilakis böyle kullanımların Arap diline uygun olduğuna delil olarak kabul edildiği görülmüştür.

Zarûret olgusu hakkında bu ihtilâfların olmasının sebebi dil bilginlerin şiir dili ile nesir dilini birbirinden ayırt etmemelerinden kaynaklanmaktadır. Dil bilginleri normal kelamda ortaya koydukları dil kaidelerini şiire de uygulamak istediklerinden şiirdeki vezin ve kâfiye zorunluluğundan ötürü normal kelamdaki dil kaidelerine aykırı gelen kullanımları, zarûret olgusu olarak değerlendirmişlerdir.

Diğer taraftan bu çalışmada şiirde dil kurallarına aykırı olarak gelen kullanımların şiir diline has bir olgu olarak ele alınıp kuraldışı kullanımlar kategorisinden çıkarılması önerisinin dikkate değer olduğu sonucuna da ulaşılmıştır. 


\section{Kaynakça}

Abdulḥalîm, Muhammed Selîm b Ḥuseyn. Mevâridu'l-beșâir li-ferâidi'ḍ-ḍarâir. thk. Hâzim Se’îd Yûnus. Ammân : Dâru Ammâr, 2000.

Abdullatîf, Muhammed Hammâse. Luggatu'ş-şi'r: dirâse fi'ḍ-ḍarûreti'ş-şi'riyye. Kahire: Dâru'şŞurûk, 1996.

Abdurrahim, Cevâd Husnî. "Mevḳifu İbn Cinnî mine'ḍ-ḍarûrâti'ş-şi'riyye". Câmi'etu'dDuveli'l-'Arabiyye-el-Lisânu'l-'Arabî. 21 (1983), 37-45.

Âlûsî, Mahmud Şukrî. eḍ-Darâir ve mâ yesûğu li'ş-şâ'ir dûne'n-nâsir. Bağdad: el-Mektebetu'l'Arabiyye, 1922.

Bağdâdî, Abdulkadir. Hizânetu'l-edeb ve lubbu lubâbi lisâni'l-'arab. thk. Abdusselâm Hârûn. 4. Basım. 13 Cilt. Misır: Mektebetu'l-Hâncî, 1997.

Bânâ'ime, Adil Ahmed Sâlim. eḍ-Darûretu'ş-şi'riyye fi'ş-şi'ri'l-ḥurr. Mekke: Câmi'etu Ummi'lKurâ, 2016.

Butrus, el-Bustânî. Muhîtu'l-muhît kâmûs muțavval li'l-lugiati'l-'arabiyye. Beyrut: Mektebetu Lübnan, 1977.

Cevherî, İsmâil b. Hammâd. Tâcu'l-lugga ve șihâhhu'l-'Arabiyye. thk. Ahmed Abdulğafûr 'Atâr. 4. Basım. 7 Cilt. Beyrut: Dâru'l-'Ulûm li'l-Melâyîn, 1990.

Cum'a, Hâlid Abdulkerîm. Şevâhidu'ş-şi'r fì Kitabi Sîbeveyhi. Kuveyt: Mektebetu Dâri'l'Arûbe, 1980.

Delâbîc, Bâsil Miftâh Ali. Eseru şâhidi'ḍ-ḍarûreti'ş-şi'riyye fi mesâili'l-hilâfi'n-naḩvî dirâse vașfiyye tahlîliyye. İrbid: Cami'etu'l-Yermûk, Doktora Tezi, 2016.

'Edvânî, Abdulvehhab Muhammed Ali. eḍ-Darûratu'ş-şi'riyye dirâse lugiaviyye nakdiyye. Beyrut: Dâru'l-Endelüs, 1979.

Enbârî, Kemaluddin Ebu'l-Berekât. el-İnșâf fì mesâili'l-hilâf beyne'n-nahviyyîn: el-Bașriyyîn ve'lKûfiyyîn. thk. Muhammed Muhyiddin Abdulhamîd. 2 Cilt. Beyrut: Dâru'l-Fikir, ts.

‘Enbekî, Ali Abdullah Ḥuseyn. “Mefhûmu'ḍ-ḍarûreti'ş-şi'riyye 'inde İbn Malik”. Mecelletu'lustâz, Cami'etu Diyâlâ 205 (1434/2013), 163-190.

Endelüsî, Ebû Hayyân. İrtişâfu'ḍ-ḍarab min lisâni'l-'arab (ciltleri birleştirilmiş hali). thk. Receb Osman Muhammed - Abduttevvâb Ramazân. 5 Cilt. Kahire: Mektebetu'l-Hâncî, 1998.

Ezherî, Muhammed b. Ahmed. Tehzî̌bu'l-lugga. thk. Abdusselam Muhammed Harun. 17 Cilt. Şebeketu'l-Fikir, ts.

Ferâhîdî, Ḥalil b. Ahmed. Kitâbu'l-'ayn muretteben 'alâ hurûfi'l-mu'cem. thk. Abdulhamîd Hendâvî. 4 Cilt. Beyrut: Dâru'l-Kutubi'l-'İlmiyye, 2003.

Hadîsî, Hatice. eş-Şâhid ve uṣûlu'n-naḥv fi Kitâbi Sîbeveyhi. Kuveyt: Maṭbû'atu Câmi'eti Kuveyt, 1974.

Ḥandûd, İbrahim b. Salih. eḍ-Darûretu'ş-şi'riyye ve mefhûmuhâ lede'n-nahviyyîn/dirâse tațbikiyye 'alâ Elfiyyeti İbn Mâlik. Medine-i Münevvere: el-Câmi'etu'l-İslamiyye, 2001.

Hatîb, Muhammed Abdulfettâh. Davâbitu'l'-fikri'n-nahvî. Kahire: Dâru'l-Basâir, 2006.

Ḥesûn, Halil Bunyân. fi'd-Darûreti'ş-şi'riyye. Beyrut: el-Muessesetu'l-Câmi'iyye li'd-Dirâse ve'n-Neşr ve't-Tevzî́', 1403/1983.

İbn Cinnî, Ebu'l-Feth Osman. el-Hुașâiș. thk. Muhammed Ali en-Neccâr. Kahire: elMektebetu'l-'Illmiyye Dâru'1-Kutubi'l-Mıșriyye, ts.

İbn Dureyd, Ebu Bekr Muhammed b. Hasen. Kitabu Cemhereti'l-lug̀a. thk. Remzî Munîr Ba'lbekkî. 3 Cilt. Beyrut: Dâru'l-'İlm li'l-Melâyîn, 1987.

İbn Fâris, Ebu'l-Huseyn Ahmed. eș-Ṣâhib̂̂ fî fiḳhi'l-lugiati'l-'arabiyye ve mesâilihâ ve suneni'l'Arab fì kelâmihâ. thk. Ahmed Hasan Besc. Beyrut: Dâru'l-Kutubi'l-'Arabiyye, 1997. 
İbn Fâris, Ebu'l-Ḥuseyn Ahmed. Żemmu'l-hața' fi'ş-şi'r. thk. Ramazân Abduttevvâb. Misır: Mektebetu'l-Hâncî, 1980.

İbn Hişâm, Cemaluddin Abdullah b. Yusuf. Tahlị̂̂su'ş-şevâhid ve Telhîșu'l-fevâid. thk. Abbas Mustafa es-Sâlihî. Beyrut: Dâru'l-Kitâbi'l-'Arabî, 1986.

İbn Mâlik, Cemaluddin Muhammed b. Abdillah. Şerḥu'l-Kâfiye eş-şâfiye. thk. Abdulmun'im Ahmed Herîrî. 4 Cilt. Mekke: Merkezu'l-Bahsi'l-'illmî, 1982.

İbn Mâlik, Cemâluddîn Muhammed b. Abdillah. Şerḥu't-teshîl. thk. Abdurrahmân SeyyidMahtûn Muhammed Bedvî. 4 Cilt. Misır: Dâru Hecer, 1990.

İbn Mâlik, Cemâluddîn Muhammed b. Abdillah. Teshîlu'l-fevâid ve tekmîlu'l-mekâșid. thk. Muhammed Kamil Berekât. Misır: Dâru'l-Kâtibi'l-'Arabî, 1968.

İbn Manẓûr, Ebu'l-Faḍl Cemaluddin el-Enșârî. Lisânu'l-'Arab. 15 Cilt. Beyrut: Dâru Ṣâdir, 1967.

İbn 'Usfûr, Ali b. Mu'min. Darâiru'ş-şi'r. thk. Seyyid İbrahim Muhammed. 2. Basım. Beyrut: Dâru'l-Endelüs, 1982.

İbn 'Usfûr, Ali b. Mu'min. el-Mukarrib. thk. Abdullah el-Cebûrî, el-Cevârî Ahmed Abdussettar. 2 Cilt. Bağdad: Menşûrâtu Riâseti Divâni'l-Evkâaf, 1972.

İbn 'Usfûr, Ali b. Mu'min. Şerḥu Cumeli'z-Zeccâcî. 3 Cilt. Beyrut: Dâru'l-Kutubi'l-'İlmiyye, 1998.

İbrâhîm, İbrâhîm Hasan. Sîbeveyhi ve'ḍ-ḍarûretu'ş-şi'riyye. Kahire: Maṭba'atu Ḥassan, 1983.

İbrahim Mustafa, Sa'duddin. eḍ-Darûretu'ş-şi'riyye dirâse naḥiyye fî şerḥi İbn 'Aḳ̂ll. el-Alûke, ts.

'İved, Sâmî. "Mefhûmu'ḍ-ḍarûreti'ş-şi' riyye 'inde ehemmi 'ulemâi'l-'arabiyye hattâ nihâyeti'l-ḳarni'r-râbi'i'l-hicrî”. Mecelletu Dirâsât fi'l-luğati'l-'arabiyye ve âdâbihâ, Suriye. 6 (2011), 55-76.

Kartâcennî, Ebu Hasan Hazim. Minhâcu'l-buleg̉â ve sirâcu'l-udebâ. thk. Muhammed Habîb İbn Hûce. 2. Basım. Beyrut: Dâru'l-Ğarbi'1-İ̀slâmî, 1981.

Kayravânî, Ebû İshâk el-Husrî. Zehru'l-âdâb ve s_emeru'l-elbâb. thk. Muhammed Ali el-Becâvî. Kahire: Dâru İhyâi'l-Kutubi'l-'Arabiyye, 1953.

Muhammed, Seyyid İbrâhim. eḍ-Darûretu'ş-şi'riyye: dirâse uslûbiyye. Beyrut: Dâru'1-Endelüs, 1983.

Mukrim, Abdu'l-'Âl Sâlim. el-Medresetu'n-naḥviyye fî Mișır ve'ş-Şâm. Beyrut: Dâru'ş-Şurûḳ, 1980.

Mustafa, İbrahim vd. el-Mu'cemu'l-vesît. 2 Cilt. Mısır: Dâru'd-Da've, 1960.

Müberred, Ebu'l-'Abbâs Muhammed b. Yezîd. el-Muktaḍab. 4 Cilt. Kahire: Vezâretu'l-Evkââ, 1994.

Râdî, Abdulhekim. Nazariyyetu'l-luġa fi'n-nakdi'l-'arabî dirâse fì hașâiși'l-luğati'l-edebiyye min manzûuri'n-nukkâdi'l-'Arab. Kahire: el-Meclisu'l-A'lâ li's-Sakâfe, 2003.

Râvî, Ṭaha. Neẓarât fi'l-lugga ne'n-nahvv. Beyrut: Menşûrâtu'l-Mektebeti'l-Ehliyye, 1962.

Șabbân, Muhammed b. Ali. Hâşsiyetu'ș-Ṣabbân 'alâ Şerhii'l-Eşmûnî. 4 Cilt. İran: İntişâratu Zâhidî, ts.

Sîbeveyhi, Ebû Bişr 'Amr b. Osman. el-Kitâb. thk. Abdusselam Muhammed Harun. 3. Basım. 5 Cilt. Kahire: Mektebetu'l-Hâncî, 1988.

Suyûtî, Celâluddin Abdurrahmân. el-Eşbâh ve'n-nezâir fi'n-naḥv. 4 Cilt. Beyrut: Dâru'lKutubi'l-'Ilmiyye, ts.

Suyûtî, Celâluddin Abdurrahmân. el-ịktirâh fî Uș̂̂li'n-nahv. 2. Basım. Beyrut: Dâru'l-Beyrûtî, 2006. 
Suyûtî, Celâluddîn Abdurrahmân. Hem'u'l-hevâmi' fì şerḥi Cem'i'l-cevâmi'. thk. Ahmed Şemsuddin. 4 Cilt. Beyrut: Dâru'l-Kutub'il-'İlmiyye, 1998.

Şaban, Hâlid Sa'd. Uș̂̂lu'n-naḥv 'inde İbn Mâlik. Kahire: Mektebetu'l-Âdâb, 2009.

Şentemerî, Suleyman b. İsa el-A'lem. Tahșîlu 'ayni'z-zeheb min ma'deni cevheri'l-edeb fî 'ilmi mecâzâti'l-'Arab. thk. Zuheyr Abdulmuhsin Sultan. 2. Basım. Beyrut: Muessesetu'rRisâle, 1994.

Toprak, M. Faruk. "Zarûrât-1 Şi'riyye". Türkiye Diyanet Vakfı İslần Ansiklopedisi. Erişim 29 Mart 2020. https://islamansiklopedisi.org.tr/zarurat-i-siriyye.

Zebîdî, Muhammed b. Muhammed el-Murtazâ. Tâcu'l-'arûs min cevâhiri'l-kâmûs. thk. Ali elHilâlî. 2. Basım. 40 Cilt. Kahire: Matba'etu Hukûmeti'l-Kuveyt, 1987.

Zubeydî, Muhammed b. Hasan. Tabakâtu'n-nahviyyîn ve'l-luggaviyyîn. thk. Muhammed Ebu'lFaḍl İbrâhîm. 2. Basım. Kahire: Dâru'l-Me'ârif, 1984. 